\title{
Altıncı Sınıf Öğrencilerinin Kesirler ve Kesirlerdeki Toplama- Çıkarma Konusundaki Bilgilerinin Yapılandırılmasına İlişkin Tahmini Öğrenme Yol Haritası
}

\author{
Hypothetical Learning Trajectory to the Development of Sixth Grade \\ Students' Knowledge about Fractions and Addition-Subtraction in \\ Fractions

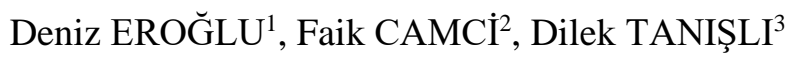 \\ • Geliş Tarihi: 09.05.2018 • Kabul Tarihi: 14.09.2018 • Yayın Tarihi: 01.01.2019
}

$\ddot{\mathbf{O} z}$

Kesirler hem öğretme hem de öğrenme açısından özellikle ilkokul matematiğinin en sorunlu ve en karmaşık konularından biridir. Öğrencilerin kesirler konusundaki başarısızlıklarının yanı sıra öğretmenlerin kesir öğretimine yönelik özensiz yaklaşımlarının ön plana çıktığı araştırmalar, kesir öğretimine yönelik araştırmalara gereksinim oluşturmaktadır. Bu gereksinimden hareketle, bu araştırmada ortaokul altıncı sınıf öğrencilerinin kesirlerde toplama ve çıkarma işlemlerini anlamalarını destekleyen bir tahmini öğrenme yol haritası geliştirmek ve aynı zamanda bu konulara yönelik bir öğretim tasarımı önermek amaçlanmıştır. Araştırmaya İç Anadolu bölgesindeki bir ilde bulunan devlet okulunda öğrenim görmekte olan gönüllü 16 altıncı sınıf öğrencisi katılmıştır. Araştırma matematik eğitiminde sıklıkla kullanılan öğretim deneyi kullanılarak tasarlanmıştır. Öğretim deneyinde beş hafta boyunca ve her hafta iki ders saati süresince veri toplanmıştır. Araştırmanın sonucunda kesir kavramı ile kesirlerle toplama ve çıkarma işlemlerine yönelik bir TÖYH geliştirilmiş ve bu konuya yönelik bir öğretim tasarımı önerilmiştir. Ayrıca önerilen öğretim tasarımında kullanılan kesirlerde toplama ve çıkarma konusu için belirlenen öğretim sırası ile kullanılan çoklu temsillerin, öğrencilerin konuları kavramsal olarak öğrenmelerine yardımcı olduğu görülmüştür.

Anahtar sözcükler: kesirlerde toplama ve çıkarma, öğretim deneyi, tahmini öğrenme yol haritası.

\section{Abstract}

Fractions are one of the most difficult and complex topics in elementary school mathematics, both in terms of teaching and learning. Indicated research results on students' failure in fractions and teachers' inadequate approaches to teaching fractions reveal the necessity of research for teaching fractions. From this point of view, the purpose of this study is to develop a hypothetical learning trajectory that supports understanding of sixth grade elementary students' addition and subtraction in fractions and to suggest a teaching design on these topics. 16 sixth grade students attended the study in a public school located on the Central Anatolia Region. This research is designed as a teaching experiment which is often used in mathematics education research. Data collection proceeded throughout mathematics classes, two class hours per week for five weeks. At the end of the teaching experiment, a hypothetical learning trajectory and a teaching design for fraction addition and subtraction was proposed. Furthermore, it was revealed that students have learned fraction operations conceptually through the teaching sequence and the multiple representations used in the proposed instructional design for teaching fraction addition and subtraction.

Keywords: addition and subtraction in fractions, hypothetical learning trajectory, teaching experiment,.

\section{Önerilen Atıf Bilgisi:}

Eroğlu, D., Camcı, F. ve Tanışlı, D. (2019). Altıncı sınıf öğrencilerinin kesirler ve kesirlerdeki toplamaçıkarma konusundan bilgilerinin yapılandırılmasına ilişkin tahmini öğrenme yol haritası. Pamukkale Üniversitesi Eğitim Fakültesi Dergisi, 45, 116-143.

\footnotetext{
${ }^{1}$ Dr. Öğr. Üyesi, Burdur Mehmet Akif Ersoy Üniversitesi, ORCİ: 000000017893 5055, deroglu@mehmetakif.edu.tr,

2 Dr. Öğretmen, Sabri Kılıçoğlu Ortaokulu, ORCID: 0000-0003-3946-8519, faikcamci02@ hotmail.com.tr

3 Doç. Dr., Anadolu Üniversitesi, ORCID: 0000-0002-2931-5079, dtanisli@anadolu.edu.tr
} 
Altıncı Sınıf Öğrencilerinin Kesirler ve Kesirlerdeki Toplama-Çıkarma Konusundaki Bilgilerinin Yapılandırılmasına İlişkin Tahmini Öğrenme Yol Haritası

\section{Giriş}

Kesirler hem öğretme hem de öğrenme açısından özellikle ilkokul matematiğinin en sorunlu ve en karmaşık konularından biridir. Yapılan pek çok araştırma ile kesirlerin karmaşıklığına yol açan ve öğrenilmesindeki güçlüklere neden olan birkaç faktör ileri sürülmüştür. En temel faktörlerden biri, kesirlerin parça-bütün, ölçme, oran, bölme ve işlemci gibi birbiriyle ilişkili çok yönlü bir yapı içerdiği gerçeğine dayanmasıdır (Behr, Harel, Post, \& Lesh, 1992; Kieren, 1993; Lamon, 2001). Bu bağlamda alan yazında ilkokuldan itibaren öğrencilerin kesirlerin bu beş alt yapısının oluşumu üzerine odaklı bir öğrenime ve öğretimine gereksinimleri olduğu ifade edilmektedir (Kieren, 1993; Lamon, 2001; Bottge, Ma, Gassaway, Butler, \& Toland, 2014). Türkiye'de 2017 yılında yayımlanan İlköğretim Matematik Dersi Öğretim Programında kesirler ile ilgili kavramlar ve beceriler birinci sınıftan başlayarak altıncı sınıfa kadar olan sürece yayılmıştır. Ancak kazanımlarda kesirlerin ağırlıklı olarak parça-bütün alt yapısına daha fazla vurgu yapıldığı (MEB, 2017) ve ayrıca öğretmenlerin kesir öğretimi ve öğreniminde nasıl bir yol izleyeceğine rehberlik edecek önemli pedagojik yolların açıkça vurgulanmadığ 1 da dikkati çekmektedir. Diğer bir ifadeyle, kesir öğretiminde kesrin farklı anlamlarının nasıl kullanılacă̆ hangi modelin hangi sıra da öğrencilere sunulacağı, ile bu anlam ve modellerin öğrencilerin sembolik kesir öğrenimini nasıl destekleyeceğine yönelik yollar öğretmenlere açık olarak sunulmamaktadır. Bunun yanı sıra, kesri anlamlı şekilde kavramsallaştırdıktan sonra kesir işlemlerini bu anlamların nasıl desteklenebileceğini gösteren yollar öğretmen için ne öğretim programında ne de ders kitaplarında açık olarak öğretmenin kullanımına sunulmamaktadır. Bu durum kimi zaman kesirlere ilişkin temel kavramsal alt yapı geliştirilmeden soyut sembolik temsillere erken ve aceleci bir geçiş yapılabileceğini de düşündürmektedir. Yapılan araştırmalar ile öğrencilerin kesirlerle ilgili birçok kavram yanılgısı taşıdığı da bulunmuştur (Pesen, 2007; Biber, Tuna ve Aktaş, 2013; DeWolf \& Vosniadou, 2015; Gökkurt, Soylu, \& Demir, 2015). Dolayısıyla kavram yanılgılarının birçoğunun kesir öğretimine özensiz yaklaşımlardan kaynaklandığı söylenebilir (Reys, Kim, \& Bay, 1999). Bu argüman çalışma kapsamında öncelikle öğrencilerin kesir bilgilerinin yapılandırılmasına yönelik bir öğretim tasarımı gerçekleştirme düşüncesini doğurmuştur. Bu düşünceden hareketle altıncı sınıf düzeyinde kesir kavramı ile kesirlerde toplama ve çıarma işlemlerine yönelik kesrin farklı alt yapılarının vurgulandığı, çoklu temsillerin kullanımına açık bir öğretim planlanmıştır. Bu planlamada diğer alt yapıları da kapsayan parça-bütün alt yapısı temel olarak ele alınmış, ancak diğer alt yapılara nazaran ölçme alt yapısına daha fazla yer verilmiştir. Ölçme alt yapısını anlayan öğrencilerin kesirlerde işlemler ve süreçte cebir öğrenme alanında akranlarına göre daha iyi performans sergilediklerine yönelik araştırma bulguları çalışmayı bu yönde şekillendirmiştir (Bailey, Hoard, Nugent, \& Geary, 2012).

Matematik eğitimi alanında temel amaç artık bilinen doğruları, bilindiği şekilde öğrencilere "anlatmak" değildir (Tunç-Pekkan, 2015). Önemli olan öğrencilerin düşüncelerini ortaya çıkararak, düşünme biçimlerini öğretime entegre edebilmektir. Nitekim uluslararas1 kuruluşlar öğretimin öğrencilerin düşüncesine dayandırılmasına gereksinim olduğunu iddia etmektedir (Common Core State Standards Initiative [CCSS], 2011; National Council of Teachers of Mathematics [NCTM], 2000). Yapılan araştırmalar öğrenimi etkili ve verimli bir şekilde yürütebilmek için öğrencilerin öğrenme süreçlerine ilişkin yol haritalarının geliştirilmesi (Simon, 1995; Simon, Tzur, Heinz, \& Kinzel, 2004; Wilson, Mojica, \& Confrey, 2013) ve 
öğretmenlerin de bu yol haritalarına dayalı ders/öğretim tasarımlarını oluşturmaları gerektiğini vurgulamaktadır (Wilson, Mojica, \& Confrey, 2013; Wilson, Sztajn, Edgington, \& Confrey, 2014). Simon (1995) bu düşünceyi modelleyen bir teorik çerçeve oluşturmuş ve bunu matematik öğretim döngüsü olarak adlandırmıştır. Bu döngünün ana unsuru Tahmini Öğrenme Yol Haritası'dır (TÖYH). TÖYH, belirli matematiksel kavramların öğrenimini planlamak için kullanılan bir araçtır. Bu araç başarılı bir ders tasarımı oluşumuna ya da başarısız bir dersin yeniden düzenlenmesine olanak tanımaktadır. Genel olarak yapılan gözlemler öğretmenlerin bir plan olmadan ya da öğrencileri yaptıkları planın dışında bırakarak, süreçte sınıf işleyiş̧ine dikkat etmeksizin, öğrenci bilgisini ve derse vereceği katkıları da göz ardı ederek ders işlediğine işaret etmektedir (Zembat, 2016). Bu ikinci argümandan hareketle de çalışma kapsamında matematik öğretim döngüsü aracılığıyla kesir kavramı ile kesirlerde toplama ve çıkarma işlemlerinin öğrenimini destekleyecek TÖYH ve öğretim etkinliklerinin hazırlanması planlanmıştır. Böylece örnek öğretim tasarımının araştırmacılara, öğretmenlere ve ders kitabı yazarlarına yardımcı ve yol gösterici olacağı düşünülmüştür. Bu bağlamda çalışmanın araştırma paradigması anlamında hem teorik hem de öğretimsel bir değeri olabileceğinden söz edilebilir. Bu bağlamda araştırmanın genel amacı, ortaokul altıncı sınıf öğrencilerinin kesirlerde toplama ve çıkarma işlemlerini anlamalarını destekleyen bir öğretim deneyini analiz ederek bir TÖYH'yi test edip geliştirmektir. Aynı zamanda kesir kavramı ile kesirlerde toplama ve çıkarma işlemlerine ilişkin bir öğretim tasarımı önermektir.

$\mathrm{Bu}$ genel amaç doğrultusunda aşağıdaki sorulara yanıt aranmıştır:

1. Kesir kavramı ile kesirlerde toplama ve çıkarma işlemlerine ilişkin etkinlikleri geliştirme sürecinde alınan tasarım kararları nelerdir ve bu kararlar neden alınmıştır?

2. Kesir kavramı ile kesirlerde toplama ve çıarma işlemlerine ilişkin test edilerek geliştirilen TÖYH'nin son hali nasıldır?

\section{Teorik Çerçeve}

\section{Tahmini Öğrenme Yol Haritası}

Matematik öğrenimi ve öğretiminin nasıl birbirleriyle etkileşimli olduğunu modelleyen Simon (1995), Şekil 1'de görülen bir teorik çerçeve oluşturmuş ve bunu Matematik Öğretim Döngüsü (MÖD) olarak isimlendirmiştir. MÖD; en sade haliyle "Öğrenci Bilgisini Değerlendirme, Öğretmen Bilgisi ve TÖYH olmak üzere üç bileşenden oluşmaktadır. Simon, TÖYH'yi MÖD’nin ana bileşeni olarak ele almıştır. Çünkü TÖYH, öğrenme ile öğretme arasında köprü kuran yapılandırmacı öğretim modellerinden biri olarak görülmektedir (Simon, 1995; 2014). 
Altıncı Sınıf Öğrencilerinin Kesirler ve Kesirlerdeki Toplama-Çıkarma Konusundaki Bilgilerinin Yapılandırılmasına İlişkin Tahmini Öğrenme Yol Haritası

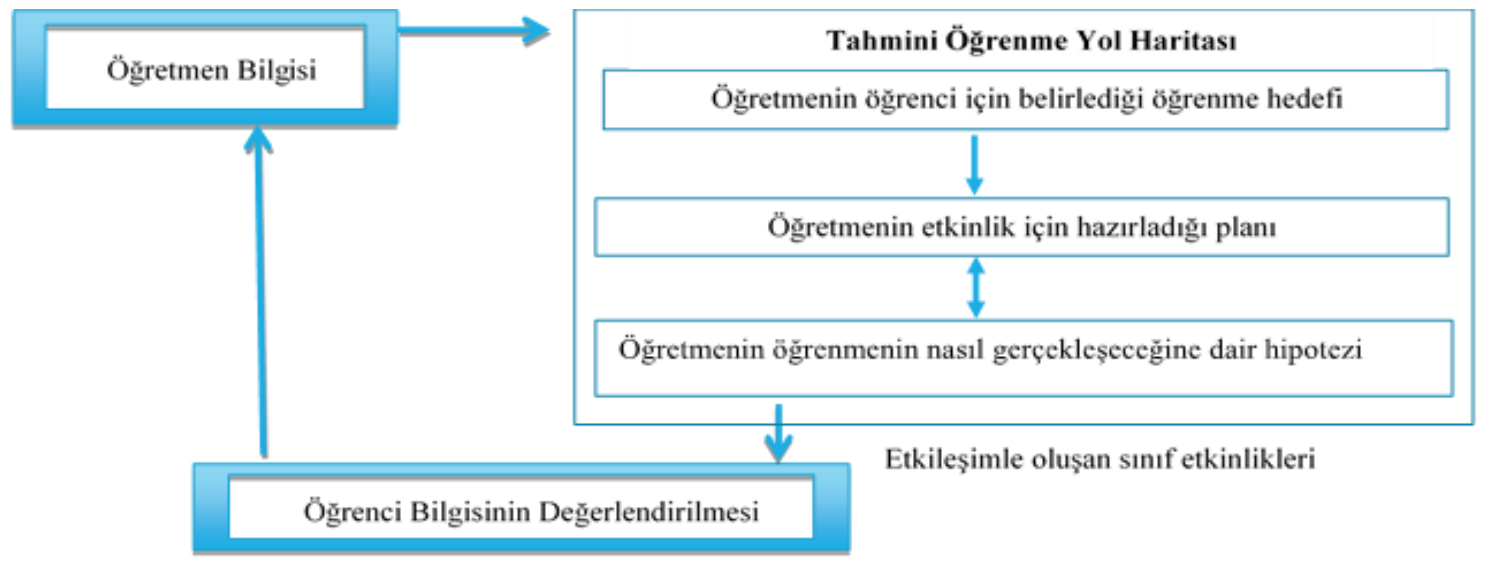

\section{Şekil 1. Matematik Öğretim Döngüsü ve TÖYH (Simon, 1995)}

Simon (1995, s.135), TÖYH’yi “öğrenmenin ilerleyebileceği yola ilişkin öğretmenin tahmini” olarak ifade etmiştir. Öğretmen, öğrenme sürecinin nasıl gerçekleşeceğini tam olarak bilemeyeceğinden dolayı 'tahmini' ifadesi kullanılmıştır. Başka bir deyişle gerçek yol haritasının daha önceden bilinmesi mümkün değildir. TÖYH'nin oluşumunda üç bileşen göz önünde bulundurulur: 1. Öğrenme hedefleri, 2. Öğrenimi destekleyecek etkinlikler ve 3. Öğrenmenin nasıl gerçekleşeceğine dair hipotezler (Simon, 1995; Simon \& Tzur, 2004). Belirlenen öğrenme hedefleri aslında diğer bileşenlere de yol göstermektedir. Öte yandan etkinliklerin planlamasında öğrenmenin nasıl gerçekleşeceğine dair ortaya konulmuş hipotezler göz önünde bulundurulur. Hipotezler ise planlanmış olan etkinliklere dayanmaktadır. Diğer bir ifadeyle bu iki bileşen arasında çift yönlü bir ilişki söz konusudur. Bu bileşenler göz önünde bulundurularak bu araştırmada kesir kavramı ile kesirlerde toplama ve çıkarma işlemlerine ilişkin TÖYH ortaya konulmuştur. Araştırmada öğrencinin öğrenimine yönelik de iki ana öğrenme hedefi belirlenmiştir. Birincisi "farklı temsiller kullanarak kesir fikri için eş parçalara ayırmanın sezgisel anlamından parça-bütün başta olmak üzere ölçme anlamına geçiş yapmanın yanı sıra oran, bölme ve işlemci anlamlarına da vurgu yapmaktır”. Birinci hedefe dayalı olarak ikinci hedef de "kesirlerde toplama ve çıkarma işlemlerini anlamlandırmaktır". Bu iki öğrenme hedefi ile ilişkili olarak da alanyazında kesir kavramının öğrenimine yönelik çalışmalar dikkate alınarak "kavramsal öğrenmenin desteklenmesi" şeklinde hipotez belirlenmiştir. Bu hipotezle ilişkili TÖYH'nin tasarımında öğrenimi destekleyecek etkinliklerde ve ders planlamalarında ise genel olarak kesirlerin anlamına odaklanılmış ve öğretimlerde kesirlerle ilgili çoklu temsillerin (alan, uzunluk, küme, gerçek hayat bağlamları) kullanımına yer verilmiştir.

\section{Yöntem}

\section{Katılımcilar}

Araştırmaya İç Anadolu bölgesindeki bir ilde bulunan devlet okulunda öğrenim görmekte olan gönüllü 16 altıncı sınıf öğrencisi katılmıştır. Bu öğrencilerin seçiminde amaçlı örnekleme yöntemlerinden biri olan ölçüt örnekleme kullanılmıştır (Yıldırım ve Şimşek, 2011). Sayılar ve işlemler öğrenme alanına ait kesirlerde toplama ve çıkarma işlemleri konusunun kazanımlarının en geniş biçimiyle altıncı sınıfta yer almasından dolayı öğrencilerin altıncı sınıfta öğrenim görmeleri, araştırmada temel ölçüt olarak belirlenmiştir. 


\section{Araştırma Deseni: TÖYH'nin geliştirilmesine Yönelik Gerçekleştirilen Öğretim Deneyi}

Araştırma matematik eğitiminde sıklıkla kullanılan öğretim deneyi kullanılarak tasarlanmıştır. Öğretim deneylerinde öğrenenin ne öğrenebileceği ve bu öğrenmeyi destekleyecek yollara ilişkin hipotezlerin oluşturulması hedeflenmektedir. Ayrıca, öğretim deneylerinin öğrencilerdeki matematiksel kavramların gelişimine dair bilgiye önemli katkılar sunduğu belirtilmektedir (Steffe \& Thompson, 2000). Bu bağlamda araştırmada kesir kavramı ile kesirlerde toplama ve çıkarma işlemlerinin öğretimine yönelik bir TÖYH'nin oluşturulması sürecinde öğretim deneyinden yararlanılmıştır. Diğer taraftan bakıldığında da TÖYH öğretim deneyinde kullanılacak görevleri oluşturmak ve düzenlemek için bir çerçeve sunmaktadır. Bu açıdan da TÖYH öğretim deneyi desenini kullanan araştırmalar içinde kullanışlı bir araç olarak ifade edilmektedir (Simon \& Tzur, 2004). Bu araştırmada da TÖYH, öğretim deneyinin gerçekleştirilmesinde araştırmacılara pedagojik bir yol olarak rehberlik etmiştir.

Öğretim deneyi, i) öğretimin tasarlanması ve planlanması, ii) öğretimin sınıf içinde uygulanması, iii) geriye dönük analiz olmak üzere üç aşamadan oluşmaktadır. Bu araştırma kapsamında gerçekleştirilen öğretim deneyi, Şekil 2'de gösterildiği şekilde döngüsel bir süreçte beş hafta boyunca devam etmiş ve her hafta iki ders saati süresince gerçekleştirilmiştir. Araştırmanın sonucunda kesir kavramı ile kesirlerle toplama ve çıkarma işlemlerine yönelik bir TÖYH geliştirilmiştir.

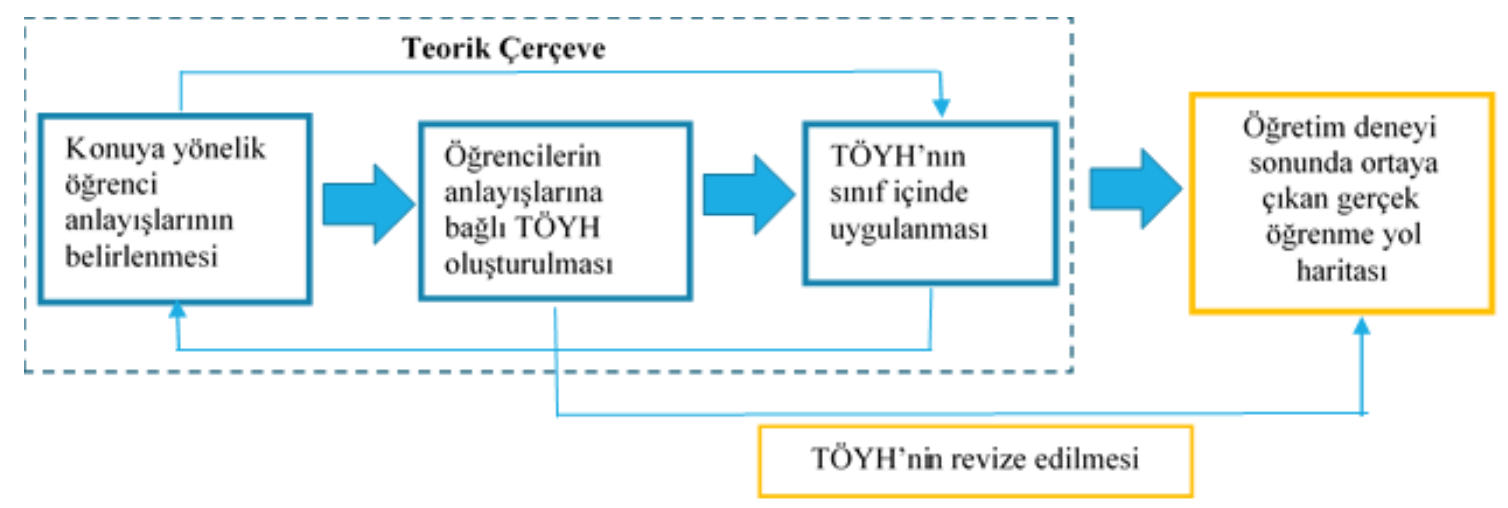

\section{Şekil 2. TÖYH'nin geliştirilmesi sürecinde gerçekleștirilen öğretim deneyi}

TÖYH yapısı oluşturulurken dört temel varsayım kullanılmıştır (Simon \& Tzur, 2004). Bu dört temel varsayıma dayalı olarak TÖYH hazırlama sürecinde öncelikli amaç "öğrencilerin kesirlerde toplama ve çıkarma işlemlerini yapabilmelerini sağlamak" olarak belirlenmiştir. Bu bağlamda öğrencilerin konuya ilişkin ön bilgilerini değerlendirmek amacıyla dokuz adet açık uçlu soru içeren bir ön test uygulanmıştır. Bu test sonucunda ve öğretmeninde görüşleri doğrultusunda öğrencilerin kesrin anlamı, kesri tanıma, birim kesir ve kesir çeşitleri konularında güçlükler yaşadıkları görülmüştür. Dolayısıyla yaşanılan bu güçlükler dikkate alınarak belirlenen amaç "öğrencilerin kesir kavramı ile kesirlerde toplama ve çıkarma işlemlerini yapabilmelerini sağlamak" olarak yeniden düzenlenerek kesir kavramı ile kesirlerde toplama ve çıkarma işlemlerinin öğretimine yönelik bir TÖYH ve buna ilişkin de ders planları hazırlanmıştır. Ders planlarında kullanılan örnek öğretim etkinlikleri Ek-1'de sunulmuştur.

TÖYH'ye dayalı ders planlarında öğrenciler için öğrenme amaç ve etkinlikleri belirlenmiş ve öğrenme süreci içerisinde öğrencilerin ilerleyişlerine yönelik tahminlerde 
Altıncı Sınıf Öğrencilerinin Kesirler ve Kesirlerdeki Toplama-Çıkarma Konusundaki Bilgilerinin Yapılandırılmasına İlişkin Tahmini Öğrenme Yol Haritası

bulunulmuştur. Hazırlanan TÖYH etkinliklerinde ise kesirlerde toplama-çıkarma işleminin öğrenimini destekleyeceği düşünülen parça-bütün alt yapısı ile ölçme alt yapısına ağırlıklı olmakla birlikte bütün alt yapılara planlamalarda yer verilmiştir. Öğretim etkinliklerinin hazırlanmasında ayrıca kesir kavramının öğrenimini desteklediği vurgulanan bütün temsil çeşitlerinin (Ball, 1993; Behr, Lesh, Post, \& Silver, 1983; Fennell \& Karp, 2017) kullanımına da önem verilmiştir. Uygulama sırasında her iki dersin öğretimi sonunda öğretmen ile bir araştırmacı, uzman bir matematik eğitimcisi ile birlikte ders sırasında ortaya çıkan öğrenme güçlüklerini belirlemiş ve ders sonlarında öğrencilere uygulanan test ve öğrenci ödevleri ile de destekleyerek bir sonraki öğretim için TÖYH ders planlarını revize etmişlerdir. Tablo 1'de hazırlanmış olan TÖYH sunulmuştur.

Tablo 1. Öğrencilerin ön bilgileri dikkate alınarak hazırlanmış TÖYH

\begin{tabular}{|c|c|c|c|c|}
\hline \multicolumn{4}{|c|}{ Öğrenme Hedefi } & Ŏğrenmeye Dair Hipotez \\
\hline \multicolumn{4}{|c|}{$\begin{array}{l}\text { 1. Farklı temsiller kullanarak kesir fikri için eş parçalara ayırmanın } \\
\text { sezgisel anlamından parça-bütün başta olmak üzere ölçme } \\
\text { anlamına geçiş yapma yanı sıra oran, bölme ve işlemci anlamlarına } \\
\text { da vurgu yapmak, } \\
\text { 2. Kesirlerde toplama ve çıkarma işlemlerini anlamlandırmak. }\end{array}$} & $\begin{array}{l}\text { amsal öğrenmeyi } \\
\text { klenmek }\end{array}$ \\
\hline & Amaç & \multicolumn{2}{|c|}{ Etkinlikler } & Öğrencilerin Őğrenme \\
\hline \multirow[t]{2}{*}{1} & \multirow[b]{2}{*}{ 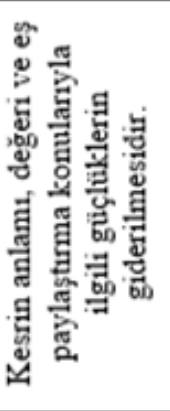 } & 1. Ders & 2. Ders & $\begin{array}{c}\text { İlerleyișine Yönelik } \\
\text { Tahminler }\end{array}$ \\
\hline & & $\begin{array}{l}\text {-Günlük yaşamdan } \\
\text { kesir örnekleri } \\
\text {-Kesre örnek olan ve } \\
\text { olmayan modeller } \\
\text { oAlan, uzunluk, } \\
\text { küme modelleri ile } \\
\text { gerçek yaşam } \\
\text { modelleri }\end{array}$ & $\begin{array}{l}\text {-Eş parçalara } \\
\text { ayırma } \\
\text { oAlan modelini } \\
\text { farklı yollarla eş } \\
\text { parçalara ayırma } \\
\text { oKüme modeli } \\
\text { üzerinde kesre } \\
\text { karşılı gelen } \\
\text { sayıyı bulma } \\
\end{array}$ & $\begin{array}{l}\text {-Kesirleri, pay ve } \\
\text { paydadaki doğal sayılarla } \\
\text { ilişkilendirebilir, } \\
\text {-Kesir parça-bütün ilişkisi } \\
\text { olarak düşünülebilir } \\
\text { - Küme modelini tek bir } \\
\text { bütün olarak düşünüp } \\
\text { anlamada zorluk } \\
\text { yaşanabilir }\end{array}$ \\
\hline \multirow[t]{2}{*}{2} & & 3. Ders & 4. Ders & \\
\hline & 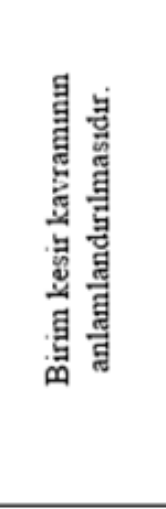 & $\begin{array}{l}\text {-Kesrin anlamının } \\
\text { hatırlatılması } \\
\text {-Alan modelinin farklı } \\
\text { yollarla eş parçalara } \\
\text { ayrılması } \\
\text { O Kesir değerinin } \\
\text { belirlenmesi } \\
\text { O Birim kesrin } \\
\text { belirlenmesi } \\
\text { Denk kesir } \\
\text { kavramının } \\
\text { tartışılması }\end{array}$ & $\begin{array}{l}\text {-Daire modeli } \\
\text { üzerinde kesre } \\
\text { örnek olan ve } \\
\text { olmayan } \\
\text { durumların } \\
\text { incelenmesi } \\
\text {-Daire modelinin } \\
\text { eş parçalara } \\
\text { ayrilması } \\
\text {-Kesir kadarı } \\
\text { verilmiş } \\
\text { modelinin } \\
\text { bütününü bulma }\end{array}$ & $\begin{array}{l}\text {-Birim kesir, kesir } \\
\text { değeriyle karıştırılabilir, } \\
\text { denk kesir, sadece pay } \\
\text { ve paydanın aynı doğal } \\
\text { sayı ile çarpılması ya da } \\
\text { bölünmesi olarak } \\
\text { düşünülebilir } \\
\text {-Daire modelinin } \\
\text { biçiminden dolayı eş } \\
\text { parçalara ayırmada } \\
\text { zorluk yaşanabilir }\end{array}$ \\
\hline
\end{tabular}




\begin{tabular}{|c|c|c|c|c|}
\hline \multirow[t]{2}{*}{3} & \multirow[b]{2}{*}{ 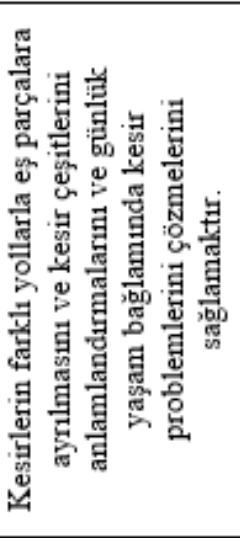 } & 5. Ders & 6. Ders & \\
\hline & & $\begin{array}{l}\text {-Kesir değeri ve birim } \\
\text { kesir hatırlatması } \\
\text {-Şekilleri farklı yollarla } \\
\text { eş parçalara ayırma }\end{array}$ & $\begin{array}{l}\text {-Bileşik kesirleri ve } \\
\text { tam say1lı kesirleri } \\
\text { birbirine } \\
\text { dönüştürme } \\
\text {-Günlük yaşam } \\
\text { problemleriyle eş } \\
\text { paylaştırma } \\
\text {-Günlük yaşam } \\
\text { problemlerinde } \\
\text { belli bir miktarı } \\
\text { bütün miktarı } \\
\text { cinsinden kesir } \\
\text { olarak ifade etme }\end{array}$ & $\begin{array}{l}\text {-Tam sayılı kesirleri, } \\
\text { anlamdan yoksun biçimde } \\
\text { bileşik kesre } \\
\text { dönüştürebilir } \\
\text {-Günlük yaşam } \\
\text { problemlerini anlamada ve } \\
\text { bu problemlerde belli bir } \\
\text { miktarı kesir olarak ifade } \\
\text { etmede zorluk yaşanabilir }\end{array}$ \\
\hline \multirow[t]{2}{*}{4} & \multirow[b]{2}{*}{ 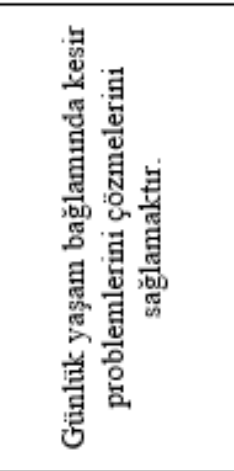 } & 7. Ders & 8. Ders & \\
\hline & & $\begin{array}{l}\text {-Günlük yaşam } \\
\text { problemlerinde belli bir } \\
\text { miktarı bütün miktarı } \\
\text { cinsinden kesir olarak } \\
\text { ifade etme } \\
\text {-Verilen bir kesri eş } \\
\text { parçalara ayırma }\end{array}$ & $\begin{array}{l}\text {-Bileşik kesir } \\
\text { kadarı verilen } \\
\text { miktarlarda bütüne } \\
\text { düşen miktarı } \\
\text { belirleme } \\
\text {-Verilen bir kesri eş } \\
\text { parçalara ayırma }\end{array}$ & $\begin{array}{l}\text {-Bileşik kesir kadarı } \\
\text { verilen miktarlarda bütüne } \\
\text { düşen miktarı belirlemede } \\
\text { zorluk yaşanabilir } \\
\text {-Kesir kadarı verilmiş } \\
\text { modelinin bütününü } \\
\text { bulmadan yararlanarak } \\
\text { Bileşik kesir kadarı } \\
\text { verilen miktarlarda bütüne } \\
\text { düşen miktarı } \\
\text { belirleyebilir }\end{array}$ \\
\hline \multirow[t]{2}{*}{5} & \multirow[b]{2}{*}{ 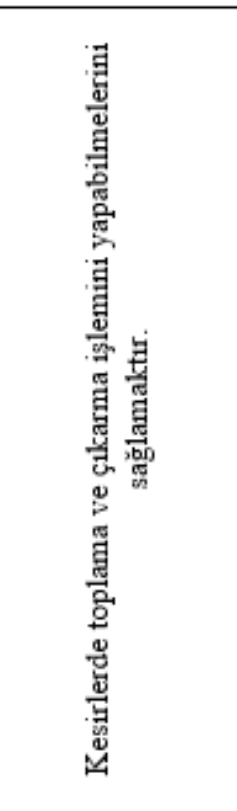 } & 9. Ders & 10. Ders & \\
\hline & & $\begin{array}{l}\text {-Paydaları eşit olan iki } \\
\text { kesri toplarken } \\
\text { paydanın neden aynı } \\
\text { alındığının tartı̧ılması } \\
\text {-Paydaları eşit olmayan } \\
\text { iki kesri toplarken } \\
\text { paydaların neden } \\
\text { eşitlendiğinin tartış1lmas } 1 \\
\text { o Paydaları birbirinin } \\
\text { katı olan ( } 2 \text { ve } 4 \\
\text { gibi) kesirler } \\
\text { o Paydaları ortak bir } \\
\text { bölene sahip olan ve } \\
\text { ortak bir katta } \\
\text { eşitlenebilen } \\
\text { (paydası } 4 \text { ve } 6 \text { gibi) } \\
\text { kesirler } \\
\text { o Paydaları aralarında } \\
\text { asal olan (3 ve } 5 \\
\text { gibi) kesirler }\end{array}$ & $\begin{array}{l}\text {-Günlük yaşam } \\
\text { bağlamındaki } \\
\text { kesirlerde toplama } \\
\text { ve ç1karma işlemi } \\
\text { problemleri }\end{array}$ & $\begin{array}{l}\text {-Kesri, kesrin anlamlarını } \\
\text { ve denk kesir kavramını } \\
\text { yapılandirmasıyla birlikte } \\
\text { toplama ve çıkarma } \\
\text { işlemlerini } \\
\text { yapilandırılabilir }\end{array}$ \\
\hline
\end{tabular}

\section{Verilerin Toplanması ve Analizi}

Öğretim süreci, 8 yıl deneyime sahip, aynı zamanda matematik eğitimi üzerine araştırmalar yürüten uzman bir matematik öğretmeni tarafından yürütülmüştür. Uygulamalar sırasında öğretmene uzman bir matematik eğitimi araştırmacısı da eşlik etmiştir. Öğretim deneyine başlamadan önce öğrencilere kesrin anlamı, şekillerin eş paylaştırılması, birim kesir, denk kesir ile problem bağlamı için kesirlerde toplama ve çıkarmaya yönelik problemler içeren ve 9 açık uçlu sorudan oluşan bir ön-test uygulanmıştır. Benzer şekilde yine 9 sorudan oluşan ancak 
Altıncı Sınıf Öğrencilerinin Kesirler ve Kesirlerdeki Toplama-Çıkarma Konusundaki Bilgilerinin Yapılandırılmasına İlişkin Tahmini Öğrenme Yol Haritası

problem bağlamı, şekil ve kesir sayıları değiştirilmiş bir son-testte araştırmanın sonunda son-test olarak öğrencilere uygulanmıştır. Bu testler araştırmayı yapan ekip tarafından hazırlanmış ve uygulanmadan önce uzman görüşleri alınmış ve testlerin bir başka öğrenci grubu üzerinde pilot çalışmaları gerçekleştirilmiştir. Öğretim deneyi boyunca gerçekleştirilen derslerin tamamı video kamera ile kayıt altına alınmıştır. Araştırma da veri kaynağı olarak uygulama öncesinde ve sonrasında uygulanan testler, derslerin video kayıtları, her hafta sonunda öğrencilere verilen ödevler ve gözlem yapan araştırmacının tutmuş olduğu alan notları kullanılmıştır.

Öğretim deneyi, sürekli analiz ve geriye dönük analiz olmak üzere iki önemli veri analiz çeşidini içermektedir. Sürekli analiz, öğrencilerle yürütülen öğretim dersleri boyunca gerçekleştirilirken; geriye dönük analiz öğretim süreci sonrasında verilerin tamamı üzerinde gerçekleştirilmektedir (Simon, 2000). Araştırmanın analiz aşamaları Şekil 3'te sunulmuştur.

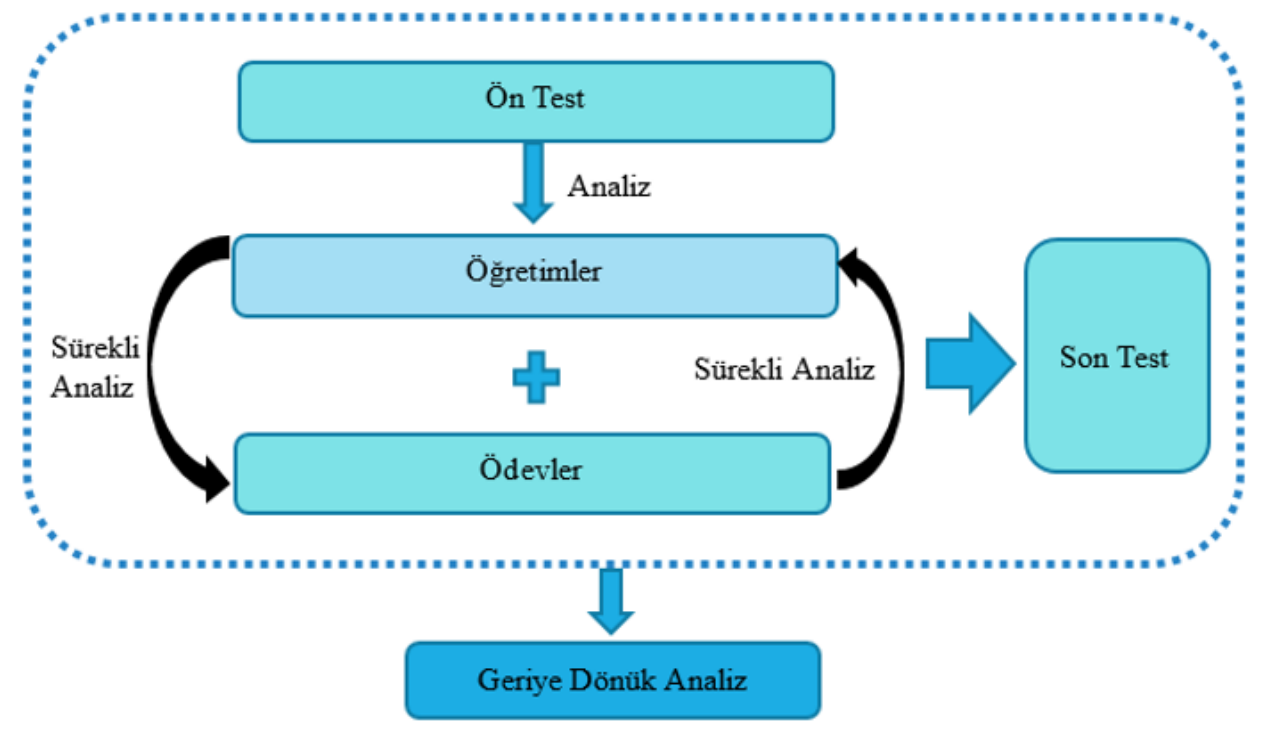

\section{Şekil 3. Veri analizinin aşamaları}

Araştırmanın sürekli analiz sürecinde uygulamayı gerçekleştiren öğretmen ve araştırmacı ile birlikte uzman bir matematik eğitimcisi, her bir dersin sonunda kaydedilen videoları izleyerek ve öğrencilere verilen ev ödevlerini inceleyerek öncelikle ders sirasında ve sonrasında öğrencilerin yaşadıkları güçlükleri, yapılandırdıkları gözlenen kavramları dikkate alarak öğretim sürecine yönelik kararlar almış, sonrasında öğretim ders planı ve etkinliklerini revize etmişlerdir. Örneğin, öğrencilerin ilk haftanın sonunda öğrencilerin farklı parçaları eş parçalara ayırma konusunda zorluklar yaşadıklarını görerek ikinci haftaya yeni modeller ile başlamaya karar vermiş ve sonrasında daha önce planlanan etkinliklerin öğretimine devam edilmiştir. Geriye dönük analiz sürecinde ise aynı ekip tarafından öğretim derslerinin dökümü yapılmış ve tüm veri kaynakları üzerinden analiz gerçekleştirilmiştir.

\section{Bulgular ve Yorumlar}

Bu bölümde ilk olarak kesirler ile kesirlerde toplama ve çıkarma işlemlerine ilişkin TÖYH'nin geliştirilmesi ifade edilmiştir. Bu bağlamda öğretim süreci haftalar bazında açıklanmış; bu süreçte öğrencilerin yaşadıkları güçlükler ve yapılandırdıkları gözlenen kavramlar dikkate 
alınarak öğretim sürecinin işleyişine yönelik alınan kararların neler olduğu ayrıntılı olarak açıklanmıştır.

\section{Tahmini Öğrenme Yol Haritası}

TÖYH'nin oluşumunun ilk aşamasında öğrencilerin ön bilgileri analiz edilmiştir. Kesirlerde toplama ve çıkarma işlemini gerçekleştirmek için gereken ön bilgileri yoklamak amacıyla hazırlanan ön test sonucunda öğrencilerde kesrin anlamı ve kesri tanıma, birim kesri belirleyememe, kesirlerin karşılaştırılması ve kesir çeşitleri konularına yönelik kavram yanılgıları ve güçlükler belirlenmiştir. Bu bağlamda kesirlerde toplama çıkarma işlemlerinin öğretimine geçmeden önce öğrencilerin kesirler konusundaki yanılg1 ve güçlüklerin giderilmesine yönelik bu durumlar bağlamında her bir hafta için bir amaç oluşturulmuş ve planlamalar yapılmıştır. Öğrencilerde ortaya çıkan bütün yanılgı ve güçlükler her bir hafta bir birini tamamlar nitelikte ilk dört hafta ön bilgilere yönelik öğretimler gerçekleştirilmiş ve öğrencilerdeki bu kavram yanılgıları ile güçlükler giderildikten sonra beşinci haftada ise kesirlerde toplama çıkarma işlemlerinin öğretimine geçilmiştir. TÖYH'nin geliştirilmesi öğretim süreci başlığı altında ayrıntılı olarak açıklanmıştır

\section{Öğretim Süreci}

\section{Birinci Hafta}

Kesrin anlamı, değeri ve eş paylaştırma konularıyla ilgili güçlüklerin giderilmesinin amaçlandığı birinci haftada öğretim öncesi, sırası ve sonrası elde edilen bulgular Tablo 2'de sunulmuştur.

Tablo 2. Birinci hafta öğretim süreci

\begin{tabular}{|c|c|c|c|}
\hline $\begin{array}{l}\text { Ön Test Sonucunda } \\
\text { Yaşanılan Güçlükler }\end{array}$ & Alınan Kararlar & $\begin{array}{c}\text { Yapılandırıldığı Gözlenen } \\
\text { Kavramlar }\end{array}$ & $\begin{array}{c}\text { Ders Sirasında ve } \\
\text { Sonrasında } \\
\text { Yaşanılan Güçlükler }\end{array}$ \\
\hline $\begin{array}{l}\text { 1. Kesri sadece biçimsel } \\
\text { ya da basit kesir olarak } \\
\text { algılama, } \\
\text { 2. Eş paylaştırmayı göz } \\
\text { ardı ederek } \\
\text { paylaştırmanın rastgele } \\
\text { olabileceğini düşünme } \\
\text { ve bütünü dikkate } \\
\text { almadan taralı parça } \\
\text { sayısını taralı olmayan } \\
\text { parça sayısına } \\
\text { oranlama, }\end{array}$ & $\begin{array}{l}\text { 1. Kesrin anlamı } \\
\text { ve değeri } \\
\text { 2. Eş paylaştırma }\end{array}$ & $\begin{array}{l}\text { 1. Kesrin eş parçalara } \\
\text { ayrılması gerektiği, } \\
\text { 2. Eş parçaların tamamının } \\
\text { bir bütünü oluşturduğu, } \\
\text { 3. Bir kesrin aynı bütünün eş } \\
\text { parçaları olması gerektiği } \\
\text { 4. Aynı bütünün farklı } \\
\text { stratejiler ile eş parçalara } \\
\text { ayırabilme, } \\
\text { 5. Farklı görünümde aynı } \\
\text { kesir değerine karşılık gelen } \\
\text { şekillerin eş parçalar } \\
\text { olduğunu anlayabilme, }\end{array}$ & $\begin{array}{l}\text { 1. Taralı parça } \\
\text { sayısını taralı olmayan } \\
\text { parça sayısına } \\
\text { oranlama } \\
\text { 2. Eş paylaştırmada } \\
\text { bir bütünü oluşturan } \\
\text { aynı büyüklükte olan } \\
\text { ancak farklı } \\
\text { biçimlerde gösterilen } \\
\text { parçaların eş } \\
\text { olduğunu anlama } \\
\text { 3. Küme modelindeki } \\
\text { her bir nesneyi bir } \\
\text { bütün olarak algılama }\end{array}$ \\
\hline
\end{tabular}

Tablo 2'de görüldüğ̈̈ gibi, ilk haftanın öğretiminde ön test sonucunda ortaya çıkan kesrin anlamı ve kesri tanımaya yönelik, kesri sadece biçimsel ya da basit kesir olarak algılama, eş paylaştırmayı göz ardı ederek paylaştırmanın rastgele olabileceğini düşünme ve bütünü dikkate almadan taralı parça sayısını taralı olmayan parça sayısına oranlama şeklindeki 
Altıncı Sınıf Öğrencilerinin Kesirler ve Kesirlerdeki Toplama-Çıkarma Konusundaki Bilgilerinin Yapılandırılmasına İlişkin Tahmini Öğrenme Yol Haritası

güçlükler göz önünde bulundurulmuştur. Örneğin kesir kavramını anlamlandırmakta zorluk yaşayan bir öğrenci kesri daha önce gördüğü şekilde biçimsel olarak açılamış ve Şekil 4'te verilen açıklamayı yapmıştır.

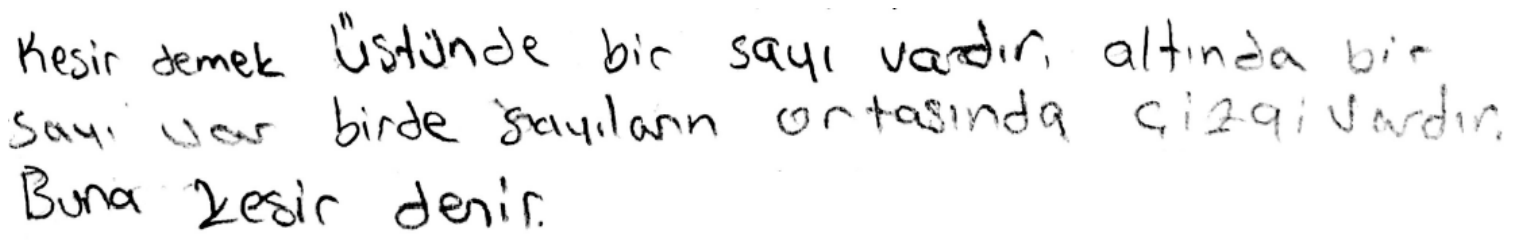

\section{Şekil 4. Kesir Tanımı}

Görüldüğü üzere öğrenci pay, payda ve kesir çizgisi üçlüsünün kesir olduğunu ifade ederek kesir kavramının anlamından yoksun bir tanım vermiştir. Zorluk yaşayan bir başka öğrenci de taralı parça sayısının taralı olmayan parça sayısına oranını Şekil 5'te verilen kesrin değeri olarak ifade etmiştir.

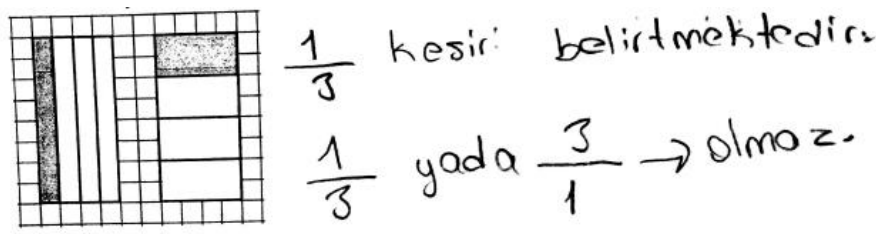

\section{Şekil 5. Öğrencinin verilen şekildeki kesir değeri}

Öğrencilerin kesir kavramına yönelik bu ve benzeri güçlüklerden yola çıkarak, öğretim sürecinin ilk haftasında kesrin anlamı ve değeri ile eş paylaştırma konularına yönelik ortaya çıkan kavram yanılgıları ve güçlüklerin giderilmesi amaçlanmıştır. Tablo 1 'de yer alan tasarım kararları aracılığıyla öğrencilerin güçlükleri giderilmiştir. Öğretim etkinliklerinde birinci ders kesir kavramına günlük yaşamdan örnekler verilerek girilmiş, kesre örnek olan ve olmayan alan, uzunluk, küme ile gerçek yaşam modelleri kullanılarak, öğrencilere kesri anlamlandırmaları ve kesir değerini belirlemeleri sağlanmıştır. İkinci ders ise, alan ve küme modelleri kullanılarak farklı yollar ile eş parçalara ayırma ve kesre karşılık gelen sayıyı bulma şeklinde eş paylaştırma etkinlikleri yapılmıştır. Öğretim etkinliğinde kullanılan modellere ilişkin bir örnek Ek-1'de sunulmuştur.

Öğretim etkinlikleri sürecinde ve sonucunda öğrencilerin öncelikle kesrin eş parçalara ayrılması gerektiğini, eş parçaların tamamının bir bütünü oluşturduğunu, bir kesrin aynı bütünün eş parçaları olması gerektiğini anladıkları görülmüştür. Sınıf içinde gerçekleşen diyaloglarda öğrencilerin kesir kavramını bir bütünün eş parçaları ile ilişkilendirdikleri, kesrin değerini ifade etmek için eş parçalardan bir kaçının alınması gerektiğini anladıkları görülmüştür. Öğrencilerin daha önceden sahip oldukları kesri biçimsel olarak tanımlama algısının değiştiği ve geliştiği görülmüştür. Öğrencilerin kesir kavramına yönelik daha ileri düzeyde düşünmelerini sağlamak için gerçekleştirilen eş parçalara ayırma etkinliklerinde öğrencilerden alan modelini farklı yollarla eş parçalara ayırmaları ve küme modeli üzerinde kesre karşılık gelen sayıyı bulmaları istenmiştir. Bu etkinlik sonucunda öğrencilerin Şekil 6'da görüldüğü gibi aynı bütünü farklı stratejiler ile eş parçalara ayırabildikleri, farklı görünümde aynı kesir değerine karşılık gelen şekillerin eş parçalar olduğunu anlayabildikleri gözlenmiştir. 


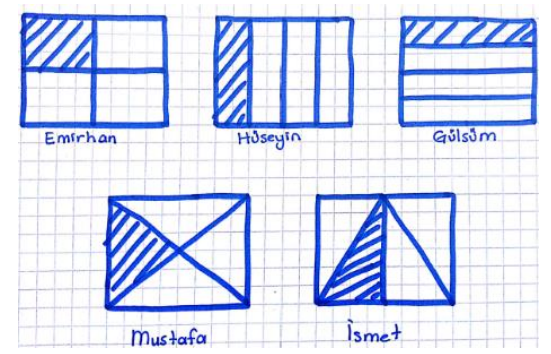

\section{Şekil 6. Farklı şekillerde eş paylaştırma}

Öğrencilerin ilk hafta sahip oldukları kazanımlar dışında uygulama sürecinde ve süreç sonunda güçlüklere de rastlanmıştır. Bu uygulama sonunda bazı öğrencilerde kesrin değerini ifade ederken halen taralı parça sayısını taralı olmayan parça sayısına oranladıkları, eş paylaştırmada bir bütünü oluşturan aynı büyüklükte olan ancak farklı biçimlerde gösterilen parçaların eş olduğunu anlamada zorlandıkları görülmüştür. Aynı zamanda öğrencilerin küme modelindeki nesnelerin tamamını bir bütün olarak algılamaktan ziyade, her bir nesneyi bir bütün olarak algıladıkları gözlenmiştir. Örneğin, "32 tane çorabın $\frac{1}{4}$ 'ine karşılık gelen çorap sayısı kaçtır?” sorusunda öğrencilerin her bir çorabı dört eş parçaya ayırma eğilimi gösterdikleri ve çorap sayısını hesaplayamadıkları görülmüştür. Bazı öğrencilerinde ayrıca "bir elmanın sapı" gibi kesirle ilgili olmayan ayrıntılara takıldıkları belirlenmiştir. İkinci haftada bu ve ön testte çıkan zorluklara yönelik etkinlik kararları alınmıştır.

\section{İkinci Hafta}

Birim kesir kavramının anlamlandırılmasının amaçlandığı ikinci haftada öğretim öncesi, süreci ve sonrasi elde edilen bulgular Tablo 3'te sunulmuştur.

\section{Tablo 3. İkinci Hafta Öğretim Süreci}

\begin{tabular}{|c|c|c|c|}
\hline $\begin{array}{c}\text { Ön Test ve Birinci } \\
\text { hafta Ödev } \\
\text { Uygulama } \\
\text { Sonucunda } \\
\text { Yaşanılan Güçlükler }\end{array}$ & Alınan Kararlar & $\begin{array}{c}\text { Yapılandırıldığı Gözlenen } \\
\text { Kavramlar }\end{array}$ & $\begin{array}{c}\text { Ders Sırasında } \\
\text { Yaşanılan Güçlükler }\end{array}$ \\
\hline $\begin{array}{l}\text { 1. Bir kesrin birim } \\
\text { kesrini belirleme } \\
\text { 2. Daire modeli } \\
\text { üzerinde eş parçalar } \\
\text { oluşturamama } \\
\text { 3. Kesir kadarı } \\
\text { verilen modelde } \\
\text { kesrin bütününü } \\
\text { belirleyememe }\end{array}$ & $\begin{array}{l}\text { 1. Kesrin anlamı } \\
\text { 2. Eş parçalara } \\
\text { ayırma } \\
\text { 3. Bir kesrin } \\
\text { birim kesrini } \\
\text { belirleme } \\
\text { 4. Denk kesir }\end{array}$ & $\begin{array}{l}\text { 1. Bir kesrin birim kesrini } \\
\text { belirleme, } \\
\text { 2. Kesirlerin denkliği, } \\
\text { 3. Aynı kesir büyüklüğüne } \\
\text { sahip farklı şekillerin eş } \\
\text { parçalar olduğunu anlama }\end{array}$ & $\begin{array}{l}\text { 1. Daire modelini } \\
\text { özellikle tek sayıda eş } \\
\text { parçaya ayırma, } \\
\text { 2. Alan modeli üzerinde } \\
\text { kesir kadarı verilen } \\
\text { miktarın bütününü bulma }\end{array}$ \\
\hline
\end{tabular}

Tablo 3'te görüldüğü gibi, ikinci haftada öğrencilerin ön-testte ortaya çıkmış bir kesrin birim kesrini belirlemeye yönelik güçlüklerin ele alınması kararlaştırılmıştır. Ayrıca birinci hafta sonunda verilen ödev sonuçlarında öğrencilerin daire modeli üzerinde eş parçalar oluşturamadıkları ve kesir kadarı verilen modelde kesrin bütününü belirleyemedikleri 
Altıncı Sınıf Öğrencilerinin Kesirler ve Kesirlerdeki Toplama-Çıkarma Konusundaki Bilgilerinin Yapılandırılmasına İlişkin Tahmini Öğrenme Yol Haritası

görülmüştür. Örneğin verilen bir daire modelini eş parçalara ayırma etkinliğinde, öğrencilerin merkez noktasını dikkate almadıkları ya da merkez noktasını dikkate alan öğrencilerin ise parçaların eşit olma durumunu göz önünde bulunduramadıkları görülmüştür. $\mathrm{Bu}$ durumu açıklayan iki model aşağıda yer almaktadır.

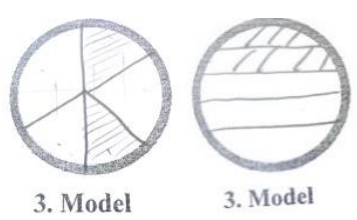

\section{Şekil 7. Hatalı eş paylaştırma}

Diğer bir zorlukta basit kesirleri temsil eden modeller verilip kesrin bütününün modelinin istendiği problemde ortaya çıkmıştır. Örneğin ${ }^{\frac{3}{4}}$ kesrini temsil eden alan modeli verilmiş ve öğrencilerden bu modele göre bütüne ait alan modelinin nasıl olacağı sorulmuştur. Öğrenciler kesrin modelini bütün olarak algılamış ve verilen kesri model üzerinde göstermişlerdir. Örnek bir öğrenci yanıtı aşağıda verilmiştir. Bu yanıtta öğrenci ilk verilen taralı kesir modelini 3/4 yerine 1 bütün olarak algılamış ve modele bütün gibi davranarak $3 / 4$ kesrini bulmak için modeli 4'e bölmüştür.

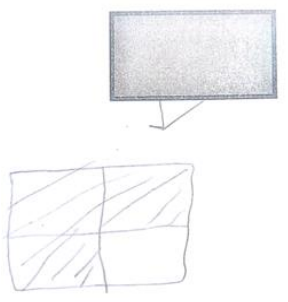

\section{Şekil 8. Verilen kesir parçasında bütünü belirlerken yapılan hata}

Öğrencilerin yaşamış oldukları bu güçlükler göz önünde bulundurularak ikinci hafta da öğrencilerin kesrin değerini belirleme, eş parçalara ayırmayla ilgili güçlüklerini gidermek, bu konuda deneyimlerini arttırmaya yönelik kararlar alınmış ve TÖYH Tablo 1'de görüldüğü şekilde hazırlanmıştır. Öğrencilerin bu hafta yaşadıkları güçlüklerini gidermek için kesir kavramının anlamına odaklanılmış ve bir parçalamanın kesir olabilmesi için eş parçalara sahip olmas1 gerektiği düşüncesi geliştirilerek güçlükler giderilmeye çalışılmıştır. Bu düşünceden hareketle öğretim etkinliklerinde alan modeli üzerinde farklı biçimlerde eş parçalara ayırma etkinlikleri yapılmış bu etkinlikler yapılırken kesir değerinin, birim kesirlerin ve denk kesirlerin belirlenmesine odaklanılmıştır. Bu etkinlikler hem öğrencilerin güçlüklerinin giderilmesi hem de toplama ve çıkarma işlemi için ön bilgi oluşturması için gerçekleştirilmiştir. Ayrıca daha önce karşılaşılan güçlüklere yönelik olarak daire modeli üzerinde kesre örnek olan ve olmayan durumları belirleme ve kesir kadarı verilmiş modelin bütününü bulma etkinlikleri gerçekleştirilmiştir. Uygulama sürecinde öğrencileri bir kesrin birim kesrini belirleme, kesirlerin denkliğini ve aynı kesir büyüklüğüne sahip farklı şekillerin eş parçalar olduğunu anlama 
yönünde bir ilerleme gözlenmiştir. Öğrenciler Görsel 1'de yer aldığ 1 şekilde üç farklı parçalama gerçekleştirmişlerdir.
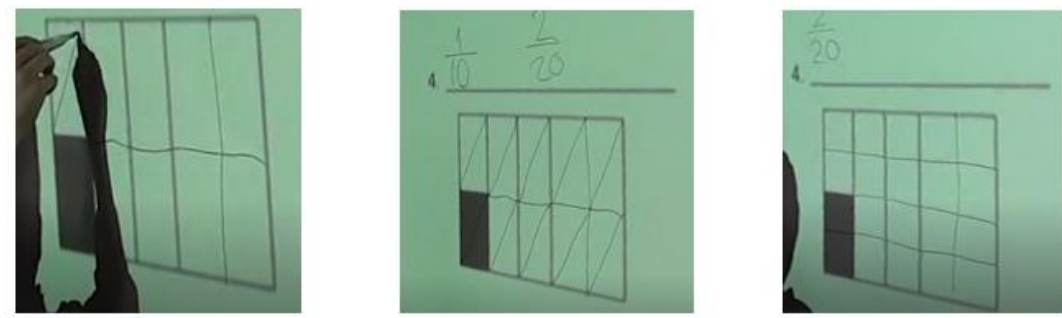

\section{Görsel 1. Aynı kesir büyüklüğü-farklı şekillere sahip eş paylaştırma}

$\mathrm{Bu}$ süreç sonunda öğrencilerde bu kavramların kazanımlarının yanı sıra uygulama sırasında güçlüklere de rastlanmıştır. Öğrencilerde daire modelini özellikle tek sayıda eş parçaya ayırmada ve alan modeli üzerinde kesir kadarı verilen miktarın bütününü bulmada yaşadıkları güçlükler Görsel 2'de görüldüğü şekilde devam etmiştir.
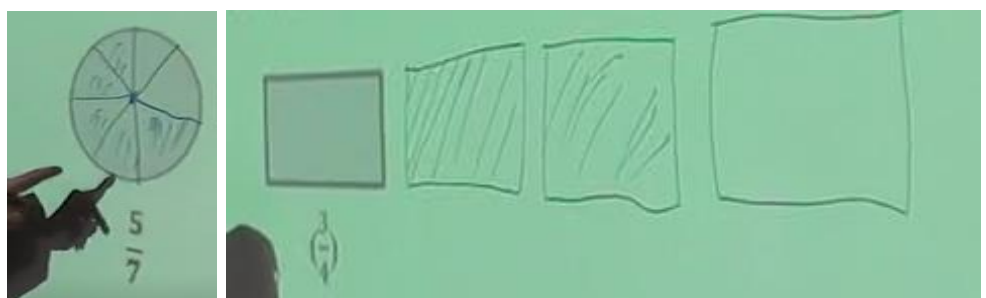

\section{Görsel 2. Öğrenci hataları}

İlk görselde görüldüğü üzere öğrenciler daireyi eş parçalara ayırma konusunda güçlük yaşamaktadırlar. Öğrencilerin daire modelini eş parçalara ayırma konusunda yaşadıkları güçlük, daire modelini 7 eş parçaya bölmek için öncelikle bütünü iki eş parçaya ayırmalarından kaynaklanmaktadır. Öğrenciler daireyi iki eş parçaya böldükten sonra; bir parçayı dörde, diğerini ise üçe böldüklerinden eş parçalar oluşturamamışlardır. İkinci görselde ise kendilerine gösterilen dörtte üçlük kısmı birim kesir olarak ele almış ve bütüne doğru şekilde ulaşamamışlardır. Bir sonraki hafta bu güçlükleri gidermeye yönelik tasarım kararları da alınmıştır.

\section{Üçüncü Hafta}

Kesirleri farklı yollarla eş parçalara ayırmanın, kesir çeşitlerinin anlamlandırılmasının ve günlük yaşam bağlamında kesir problemlerinin çözülebilmesinin amaçlandığı üçüncü haftada öğretim öncesi, sırası ve sonrası bulgular Tablo 4'te sunulmuştur. 
Altıncı Sınıf Öğrencilerinin Kesirler ve Kesirlerdeki Toplama-Çıkarma Konusundaki Bilgilerinin Yapılandırılmasına İlişkin Tahmini Öğrenme Yol Haritası

Tablo 4. Üçüncü Hafta Öğretim Süreci

\begin{tabular}{|c|c|c|c|}
\hline $\begin{array}{c}\text { Ön Test ve İkinci Hafta } \\
\text { Ödev Uygulama } \\
\text { Sonucunda Yaşanılan } \\
\text { Güçlükler }\end{array}$ & Alınan Kararlar & $\begin{array}{c}\text { Yapılandırıldığı } \\
\text { Gözlenen Kavramlar }\end{array}$ & $\begin{array}{c}\text { Ders Sirasında } \\
\text { Yaşanılan Güçlükler }\end{array}$ \\
\hline $\begin{array}{l}\text {-Farklı kesir çeşitlerinde } \\
\text { parça-bütün ilişkisini } \\
\text { kuramama } \\
\text {-Bileşik ve tam sayılı } \\
\text { kesirlerde basit kesir } \\
\text { kadarını anlamlandıramama } \\
\text {-Tam sayılı ve bileşik kesri } \\
\text { ilişkilendirememe } \\
\text {-Kesir kadarı verilmiş alan } \\
\text { modelinde kesrin bütünü } \\
\text { bulma }\end{array}$ & $\begin{array}{l}\text {-Bir kesrin kesir } \\
\text { değerini bulma, } \\
\text {-Birim kesir } \\
\text {-Bileşik şekilleri } \\
\text { farklı yollarla eş } \\
\text { parçalara ayırma } \\
\text {-Bileşik kesirleri ve } \\
\text { tam sayılı kesirleri } \\
\text { birbirine dönüştürme } \\
\text {-Günlük yaşam } \\
\text { problemleri } \\
\text { bağlamında eş } \\
\text { paylaştırma } \\
\text {-Günlük yaşam } \\
\text { problemlerinde belli } \\
\text { bir miktarı kesir } \\
\text { olarak ifade etme }\end{array}$ & $\begin{array}{l}\text {-Farklı yollarla eş } \\
\text { parçalara ayırabilme } \\
\text {-Bileşik ve tam sayılı } \\
\text { kesirleri birbirine } \\
\text { dönüştürebilme } \\
\text {-Günlük yaşam } \\
\text { problemleriyle eş } \\
\text { paylaştırma } \\
\text { yapabildikleri } \\
\text {-Günlük yaşam } \\
\text { problemlerinde belli bir } \\
\text { miktarı kesir olarak } \\
\text { ifade edebilme }\end{array}$ & $\begin{array}{l}\text {-Günlük yaşam } \\
\text { problemlerinde } \\
\text { paylaşımlardan kalan } \\
\text { parçayı paylaştırıp } \\
\text { paylaşım sonucunu } \\
\text { bileşik kesir olarak } \\
\text { ifade etme }\end{array}$ \\
\hline
\end{tabular}

Tablo 4'te görüldügü gibi, ön test sonucunda kesir çeşitlerinde ve ikinci hafta sonunda uygulanan ödev bulgularında ortaya çıkan güçlükler dikkate alınarak üçüncü hafta etkinlikleri hazırlanmıştır.

Ön test sonucunda öğrencilerin farklı kesir çeşitlerinde parça-bütün ilişkisi kuramadıkları, bileşik kesir ile tam sayılı kesirlerde basit kesir kısmını anlamlandıramadıkları ve tam sayılı kesir ile bileşik kesri ilişkilendiremedikleri görülmüştür. Bu güçlüklere verilebilecek örneklerden biri aşă̆ıda yer almaktadır.
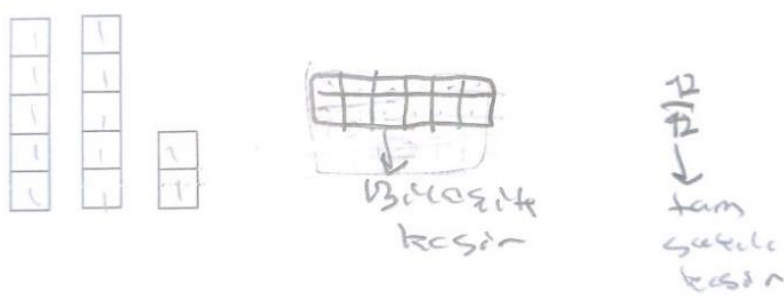

\section{Şekil 9. Öğrencilerin ön-testte tam sayılı ve bileşik kesir konusunda yaşadıkları zorlukları gösteren modeller}

$\mathrm{Bu}$ problemde beş birimlik uzunluk bir bütün olarak ifade edilmiş, öğrencilerden verilen modeli bileşik ve tam sayılı kesir olarak ifade etmeleri istenmiştir. Öğrencilerden biri bileşik kesri birleştirme olarak görmüş ve şekilleri birleştirerek yeni bir model oluşturmuş; modelini de bileşik kesir olarak adlandırmıştır. Diğer yandan öğrenci her bir birimi bir bütün olarak $\underline{12}$ düşünerek ${ }^{12}$ kesrini yazmış ve 12'yi tam sayı olarak değerlendirip kesri tam sayılı kesir olarak 
ifade etmiştir. İkinci hafta sonunda uygulanan ödev sonucunda ise öğrencilerin halen kesir kadarı verilmiş alan modelinde kesrin bütünü bulmada yaşadıkları güçlüklerin devam ettiği görülmüştür. $\mathrm{Bu}$ durumu gösteren bir örnek aşağıdaki öğrencinin temsilinde karşımıza çıkmaktadır. Öğrenciye verilen alan modelinin $\frac{2}{6}$,yi temsil ettiği ifade edilerek, öğrencilerden kesrin bütününü çizmesi istenmiştir. Ancak öğrenciler bu konuda güçlükler yaşamışlar ve yine verilen parçayı bütün olarak düşünerek bir paylaştırmaya gitmişlerdir. Aşağıda örnek bir paylaştırma görülmektedir. Şekilde öğrencinin modeli hem bütün olarak ele aldığı hem de verilen kesri de hatalı olarak gösterdiği görülmektedir.

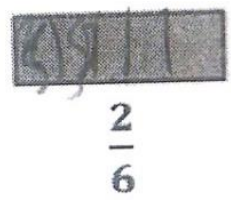

\section{Şekil 10. Hatalı kesir gösterimi}

Öğrencilerde görülen bu güçlüklerden yola çıkarak üçüncü hafta etkinliği hazırlanmış ve iki ders saati sürecek eş parçalara ayırma, kesir çeşitleri ve problemleri kazanımlarını içeren bir ders planı geliştirilmiştir. Beşinci dersin öğretim etkinliklerinde bir kesrin kesir değerini bulma, birim kesrini hatırlatma ve birleşik şekilleri farklı yollarla eş parçalara ayırma etkinlikleri gerçekleştirilmiştir. Sonrasında ise bileşik kesirleri ve tam sayılı kesirleri birbirine dönüştürmeye, günlük yaşam problemleri bağlamında eş paylaştırmaya ve günlük yaşam problemlerinde belli bir miktarı kesir olarak ifade etmeye yönelik etkinlikler yürütülmüştür.

Öğretim etkinlikleri sırasında beşinci derste şekilleri farklı yollarla eş parçalara ayırabildikleri gözlenmiştir. Altıncı ders sırasında ise, bileşik kesirleri ve tam sayılı kesirleri birbirine dönüştürebildikleri, günlük yaşam problemleriyle eş paylaştırma yapabildikleri ve günlük yaşam problemlerinde belli bir miktarı kesir olarak ifade edebildikleri görülmüştür.

İki ders sonunda yukarıda ifade edilen kazanımların yanı sıra öğrencilerde günlük yaşam problemlerinde paylaşımlardan kalan parçayı paylaştırıp paylaşım sonucunu bileşik kesir olarak ifade etmede güçlüklerin devam ettiği görülmüştür. Ayrıca kesirleri birbirine dönüştürmede payda ile tam kısmın çarpılıp payın eklenmesi gibi ön öğrenmelerin olumsuz etkisinin de güçlüklere yol açtığı gözlenmiştir.

\section{Dördüncü Hafta}

Kesirlerin farklı yollarla eş parçalara ayırmanın, kesir çeşitlerinin anlamlandırılmasının ve günlük yaşam bağlamında kesir problemlerinin çözülebilmesinin amaçlandığı dördüncü haftada öğretim öncesi, sırası ve sonrası bulgular Tablo 5'te sunulmuştur. 
Altıncı Sınıf Öğrencilerinin Kesirler ve Kesirlerdeki Toplama-Çıkarma Konusundaki Bilgilerinin Yapılandırılmasına İlişkin Tahmini Öğrenme Yol Haritası

Tablo 5. Dördüncü Hafta Öğretim Süreci

\begin{tabular}{|c|c|c|}
\hline $\begin{array}{c}\text { Ön Test ve Üçüncü Hafta } \\
\text { Ödev Uygulama Sonucunda } \\
\text { Yaşanılan Güçlükler }\end{array}$ & Alınan Kararlar & $\begin{array}{c}\text { Yapılandırıldığı Gözlenen } \\
\text { Kavramlar }\end{array}$ \\
\hline $\begin{array}{l}\text {-Eş paylaştırma } \\
\text {-Bileşik kesir kadarı verilen } \\
\text { miktarlarda bütünü belirleme }\end{array}$ & $\begin{array}{l}\text {-Günlük yaşam problemleri } \\
\text { bağlamında belli bir miktarı bütün } \\
\text { miktarı cinsinden kesir olarak } \\
\text { ifade etme } \\
\text {-Eş paylaştırma } \\
\text {-Bileşik kesir kadarı verilen } \\
\text { miktarlarda bütünü belirleme ve } \\
\text { verilen bir kesri eş parçalara } \\
\text { ayırma }\end{array}$ & $\begin{array}{l}\text {-Günlük yaşam problemleri } \\
\text { bağlamında belli bir miktarı } \\
\text { bütün miktarı cinsinden kesir } \\
\text { olarak ifade etme, } \\
\text {-Bileşik kesir kadarı verilen } \\
\text { miktarlarda bütünü belirleme ve } \\
\text { verilen bir kesri eş parçalara } \\
\text { ayırma }\end{array}$ \\
\hline
\end{tabular}

Tablo 5'te görüldüğü gibi, üçüncü hafta sonunda uygulanan ödev bulgularında bileşik kesir kadarı verilen miktarlarda bütünü belirlemede ve bazı öğrencilerde verilen bir kesir modelini eş parçalara ayırmada güçlüklerin devam ettiği göze çarpmaktadır. Öğrencilerin bu güçlüklerini gösteren bir durum 24 yıldızın $8 / 5$ 'i ifade ettiği belirtilerek, öğrencilerden bir bütüne düşen sayıyı belirlemeleri istenen problemde görülmektedir. Örneğin öğrencilerden biri belirtilen problemde bileşik kesir kadarı verilen miktarlar içinde birim kesri ve birim kesre düşen yıldız sayısını doğru şekilde belirlemesine rağmen; bütüne düşen miktarı aşağıdaki şekilde hatalı olarak ifade etmiştir.

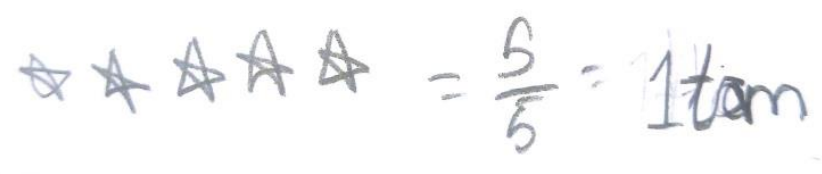

\section{Şekil 11. Öğrencinin küme modelin üzerinde yapmış olduğu hata}

Öğrencilerde görülen bu güçlüklerden yola çıkarak dördüncü hafta etkinliği hazırlanarak iki ders saati sürecek günlük yaşam problemleri ve eş parçalara ayırma kazanımlarını içeren bir ders planı geliştirilmiştir. Öğretim etkinliğinde yedinci ders günlük yaşam problemleri bağlamında belli bir miktarı bütün miktarı cinsinden kesir olarak ifade etmeye ve verilen bir kesri eş parçalara ayırmaya yönelik etkinlikler gerçekleştirilmiştir. Sekizinci ders ise; bileşik kesir kadarı verilen miktarlarda bütünü belirlemeye ve verilen bir kesri eş parçalara ayırmaya yönelik etkinlikler yürütülmüştür.

Öğretim etkinlikleri sırasında ve sonunda öğrencilerde günlük yaşam problemleri bağlamında belli bir miktarı bütün miktarı cinsinden kesir olarak ifade etme, bileşik kesir kadarı verilen miktarlarda bütünü belirleme ve verilen bir kesri eş parçalara ayırma konularında bir ilerleme olduğu gözlemlenmiştir. İki ders sonunda yukarıda ifade edilen kazanımların yanı sıra uygulama sırasında öğrencilerin herhangi bir güçlük de yaşamadıkları görülmüştür.

\section{Beşinci Hafta}

Toplama ve çıkarma yapabilmenin amaçlandığı beşinci haftada öğretim öncesi, sırası ve sonrası bulgular Tablo 6'da sunulmuştur. 
Tablo 6. Beşinci Hafta Öğretim Süreci

\begin{tabular}{|c|c|c|c|}
\hline Alınan Kararlar & $\begin{array}{c}\text { Yapılandırıldığı } \\
\text { Gözlenen } \\
\text { Kavramlar }\end{array}$ & $\begin{array}{c}\text { Ders Sırasında } \\
\text { Yaşanılan Güçlükler }\end{array}$ & $\begin{array}{l}\text { Uygulama Sonunda ve Son } \\
\text { testte Așlan Güçlükler }\end{array}$ \\
\hline $\begin{array}{l}\text {-Günlük yaşam } \\
\text { problemleri ve eş } \\
\text { parçalara ayırma } \\
\text { bağlamında } \\
\text { toplama ve çıarma } \\
\text { işlemlerini } \\
\text { yapabilme }\end{array}$ & $\begin{array}{l}\text {-Toplama ve çıkarma } \\
\text { işlemlerini yapabilme }\end{array}$ & $\begin{array}{l}\text {-Paydaları eşit olan iki } \\
\text { kesri toplarken } \\
\text { paydanın neden aynı } \\
\text { alındığı } \\
\text {-Paydaları eşit olmayan } \\
\text { iki kesri toplarken } \\
\text { paydaların neden } \\
\text { eşitlendiği }\end{array}$ & $\begin{array}{l}\text {-Kesirlerin eş parçalardan } \\
\text { oluşması gerektiğini kavrama } \\
\text {-Şekli verilen kesrin değerini } \\
\text { doğru olarak belirleyebilme } \\
\text {-Değeri verilen kesre uygun } \\
\text { modeli çizebilme } \\
\text {-Verilen kesri model üzerinde } \\
\text { eş parçalara ayırarak kesir } \\
\text { değerini gösterebilme } \\
\text {-Kesirlerde toplama ve çıkarma } \\
\text { işlemi yapabilme ve bu işlemler } \\
\text { için uygun modelleri çizebilme } \\
\text {-Modelleri doğru şekilde } \\
\text { parçalara ayırabilme, verilen } \\
\text { kesrin değerini belirleyebilme } \\
\text {-Toplama-çıkarma işlemi için } \\
\text { önem oluşturan birim kesrin } \\
\text { değerini bulabilme } \\
\text {-Toplama-çıkarma işlemini } \\
\text { kolayca gerçekleştirebilme, bu } \\
\text { işlemleri ayrıca model üzerinde } \\
\text { gösterebilme ve problem } \\
\text { çözümünde kesir işlemi } \\
\text { yapabilme }\end{array}$ \\
\hline
\end{tabular}

Tablo 6'da görüldüğü gibi, sekizinci ders sonunda sınıf tartışmaları ve bireysel ödevlere dayalı olarak öğrencilerin başlangıçta ön bilgileriyle ilgili yaşadıkları güçlük ve kavram yanılgılarının giderildiği düşünüldüğünden kesirlerde toplama ve çıkarma işlemlerine geçilmesine karar verilmiştir. Dolayısıyla beşinci hafta etkinliği hazırlanmış ve iki ders saatinde uygulanmıştır. Bu süreç sonunda öğrencilerde kazanımların olmasının yanı sıra uygulama sırasında güçlüklere de rastlanmıştır.

İki ders saati sürecek günlük yaşam problemleri ve eş parçalara ayırma bağlamında toplama ve çıkarma işlemlerini yapabilme kazanımlarını içeren bir ders planı geliştirilmiştir. Öğretim etkinliğinde dokuzuncu ders, paydaları eşit olan iki kesri toplarken paydanın neden aynı alındığının ve paydaları eşit olmayan iki kesri toplarken paydaların neden eşitlendiğinin tartışılmasına yönelik etkinlikler yürütülmüştür. Onuncu ders ise, günlük yaşam bağlamında kesirlerde toplama ve çıkarma işlemi problemlerini çözebilmeye yönelik etkinlikler gerçekleştirilmiştir.

Öğretim etkinlikleri sırasında ve sonunda öğrencilerde kesirlerde toplama ve çıkarma işlemini yapma konusunda ilerleme olduğu görülmüştür. İki ders sonunda öğrencilerin genel olarak kesir kavramı, kesrin anlamları ve denk kesir kavramını öğrenme konusunda ilerleme kaydettiklerinden dolayı kesirlerde toplama ve çıarma işlemlerini yapabilmede güçlük 
Altıncı Sınıf Öğrencilerinin Kesirler ve Kesirlerdeki Toplama-Çıkarma Konusundaki Bilgilerinin Yapılandırılmasına İlişkin Tahmini Öğrenme Yol Haritası

yaşamadan ilerleme kaydettikleri görülmüştür. Bununla birlikte uygulama sırasında birkaç öğrencide kesirlerde toplama-çıkarma işlemine ilişkin ön öğrenmelerin etkisinin güçlüklere yol açtığ 1 görülmüştür. Bu güçlüklerin paydaları eşit olan iki kesri toplarken paydanın neden aynı alındığını ve paydaları eşit olmayan iki kesri toplarken paydaların neden eşitlendiğini açıklayamamaları ile ilgili olduğu saptanmıştır. Bununla birlikte bu öğrencilerin yaşadıkları bu güçlükleri uygulama sırasında aşabilmişlerdir.

Uygulama sırasında karşılaşılan güçlüklerin aşıldığı öğrencilere uygulanan son teste de yansımıştır. Son testte öğrencilerin kesir kavramı, kesrin anlamları, denk kesir kavramı ve kesirlerde toplama-çıkarma bilgileri değerlendirilmiştir. Bu teste göre öğrencilerin kesirlerin eş parçalardan oluşması gerektiğini kavradıkları, şekli verilen kesrin değerini doğru olarak belirleyebildikleri, değeri verilen kesre uygun modeli çizebildikleri, verilen kesri model üzerinde eş parçalara ayırarak kesir değerini gösterebildikleri, son olarak kesirlerde toplama ve çıkarma işlemi yapabildikleri ve bu işlemler için uygun modelleri çizebildikleri görülmüştür. Örneğin öğrencilerden verilen şeklin üzerinde ${ }^{\frac{1}{4}}$ kesrini göstermeleri istenmiş ve öğrencilerin tamamı aşağıdaki örneklerde görüldüğü şekilde kesri doğru şekilde gösterebilmişlerdir.
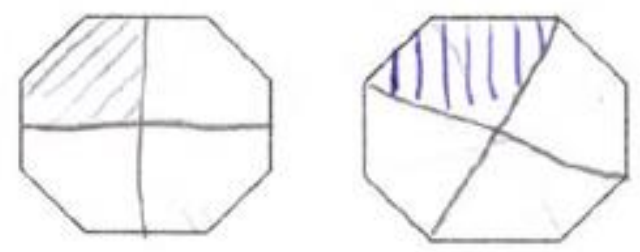

\section{Şekil 12. Öğrencilerin $\frac{1}{4}$ için oluşturdukları iki farklı parçalayış}

Öğrenciler ön testte kesrin eş parçalardan oluşması gerektiğini anlamadıkları gibi, bilenlerde düzgün parçalamayı gerçekleştiremiyordu. Ancak öğretim deneyi sonunda öğrencilerin modelleri doğru şekilde parçalara ayırabildikleri, verilen kesrin değerini belirleyebildikleri ve ayrıca toplama-çıkarma işlemi için önem oluşturan birim kesrin değerini de bulabildikleri görülmüştür. Öğrencilerin verilen model üzerinde kesrin değerini belirlemek için yaptıkları parçalama, kesrin değerini ifade edişleri ve birim kesri belirlemeleri Şekil 14'te verilen örnekte görülmektedir.

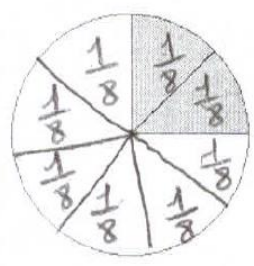

a. Kesrin değerini belirleyiniz.<smiles>[C-]1[C-]2CC1C2</smiles>

b. Birim kesrini belirleyiniz.

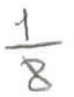

\section{Şekil 13. Eş parçalama}

Kesirlerde toplama-çıkarma işlemine ön bilgi oluşturan bu kazanımların ardından ayrıca öğrencilerin toplama-çıkarma işlemini kolayca gerçekleştirdikleri, bu işlemleri ayrıca model 
üzerinde gösterebildikleri ve problem çözümünde kesir işlemi yapabildikleri Şekil 15'te yer alan örneklerde gösterilmiştir.

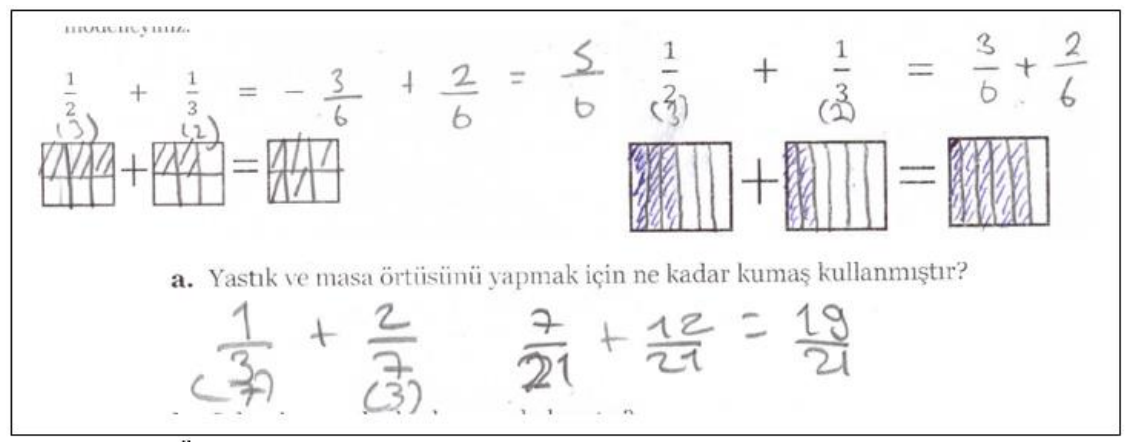

\section{Şekil 14. Kesirlerde toplama işlemlerinden örnekler}

Sonuç olarak öğrencilerin son test sonuçları hem kesir kavramını kazandıkları hem de kesirlerde toplama-çıkarma işlemlerini yapabildikleri görülmüştür.

\section{Sonuç ve Tartışma}

$\mathrm{Bu}$ araştırma da kesir kavramı ile kesirlerde toplama ve çıkarma işlemlerine yönelik TÖYH geliştirmek amaçlanmıştır. Bu amaç doğrultusunda alan-yazından elde edilen sonuçlar ile öğretmen ve araştırmacıların deneyimlerinden yola çıkılarak ve aynı zamanda ön-test uygulamasının sonucunda Tablo 1'de yer alan bir TÖYH oluşturulmuştur. Bu yol haritasının oluşumunda öğrencilerin kesirlerde toplama ve çıkarma konusunu öğrenirken öncelikle öğrenci güçlüklerinin giderilmesine, farklı temsillerin yaygın olarak kullanılmasına özen gösterilmiştir. Oluşturulan bu TÖYH'nin merkezinde kesirlerde toplama-çıkarma işlemleri için ön bilgi olduğu düşünülen ve kesir kavramının temelini oluşturan eş paylaştırma, kesrin farklı anlamları, birim kesir ve denk kesir kavramları yer almıştır. Bu kavramların öğretiminde ise uygun olan bütün farklı temsil çeşitlerinden ve günlük yaşam bağlamlarından yararlanılması planlanmıştır. Bir öğretime başlarken öğrencilerin ön bilgilerinden yararlanılması ilkesi birçok araştırmac1 tarafindan ortaya konulmaktadır (Greeno, 1997). Nitekim TÖYH'nin oluşturulmasında kullanılan temel varsayımlardan ilki de TÖYH'nin öğrencilerin sahip oldukları mevcut bilgilerine yönelik anlayışın temel alınması şeklinde açıklanmaktadır (Simon \& Tzur, 2004). Bu bağlamda araştırmanın ilk aşamasında kesirlerde toplama ve çıkarma işlemine yönelik hazırlanan TÖYH'nin öğretim uygulamalarına geçilmeden önce öğrencilerin ön bilgileri yoklanmıştır. Ön test sonucunda öğrencilerin istenilen konuyu anlamasına temel olacak kesirle ilgili kavramlarda güçlüklerin olduğu görülmüş ve bu kavramlara Tablo 1'de görüldüğü gibi her bir haftadaki etkinliklerde yer verilmiştir. Bu kararlarda amaç öğrencilerin hem ön bilgilerinde var olan güçlükleri gidermek hem de kesirlerde toplama-çıkarma işlemlerinin temelini oluşturmaya yönelik adımlar atmaktır. Araştırma uygulamasının sonunda ise ön-test sonucunda yeniden revize edilen TÖYH'nin yapısında iki temel değişikliğe gidilmiştir.

Uygulama sonrasında yapılan değişikliklerden ilki ise daire modelinin eş parçalara ayırma etkinliklerinde kullanımının ilerleyen haftalara alınması yönünde olmuştur. Öğrenciler ikinci hafta da daire modeli üzerinde kesre örnek olan ve olmayan durumlar üzerinde çalışmış, ayrıca daire modelini farklı şekillerde eş parçalara ayırma etkinlikleri yapmışlardır. Ancak ikinci hafta da yapılan bu parçalama etkinliği öğrencilerin güçlükler yaşamasına neden olmuş ve 
Altıncı Sınıf Öğrencilerinin Kesirler ve Kesirlerdeki Toplama-Çıkarma Konusundaki Bilgilerinin Yapılandırılmasına İlişkin Tahmini Öğrenme Yol Haritası

öğrenciler doğru bir parçalama gerçekleştirememişlerdir. Sonraki haftalarda daire modeli üzerine yeniden çalışmalar yapılmış ve son testte öğrencilerin daire modelini eş parçalara ayırabildikleri görülmüştür. Bu süreçten yola çıkılarak daire modelinin eş parçalara ayrılmasına yönelik etkinliklerin kullanımı için iki farklı karar alınmıştır:

1. Daire modelinin eş parçalara ayrılması etkinliği öğrenciler diğer modeller (dikdörtgensel alan modeli vb.) üzerinde uzmanlaştıktan sonra gerçekleştirilmelidir.

2. Daire modeli öncelikle çift sayıdaki parçaya ayrılarak başlamalı ve tek sayıdaki parçalamaya diğerinde uzmanlaştıktan sonra geçilmelidir.

Daire modelinin kullanımı birçok araştırmada farklı şekillerde ele alınmış kullanımına yönelik de farklı görüşler ortaya atılmıştır. Örneğin Moss ve Case (1999) araştırmalarında kesir için kullanılan daire modelinin öğrencileri tam sayı olarak düşünmeye yönelttiğini ifade etmişler ve kullanımı konusunda öğretmenleri uyarmışlardır. Buna karşın bir başka araştırmada Cramer, Post ve Delmas (2002) ise daire modelinin diğer modellere (kâğıt katlama, sayma pulları vb.) karşı en etkili yol olduğu sonucuna ulaşmışlardır. Bu araştırmalardaki farklı yorumların sebebinin modelin farklı amaçlar için kullanımlarından dolayı olduğu söylenebilir. Cramer ve arkadaşları (2002) araştırmalarında daire modelinin etkili olmasının nedenini parça ve bütün ilişkisini öğrencilerin daha kolay görebildikleri şeklinde açıklamışlardır. Diğer bir değişle daire modelinde parça sayısı arttığında bir parçaya düşen miktar azaldığından, öğrencilerin kesrin büyüyüp küçüldüğünü net bir şekilde görebildiklerini ya da bütün içinde kesrin ne kadara karşıllk geldiği görüldüğünden öğrencilerin daha kolay karşılaştırma yapabildiklerini ifade etmişlerdir. Bu yönüyle daire modelinin etkili olması açıklanan nedenlerle birlikte çok doğal bir sonuç olduğu söylenebilir. Diğer taraftan bizim çalışmamızda ise öğrencilerin daire modelinde eş paylaştırma etkinliklerinde güçlük yaşamaları onların diğer modeller üzerinde yapmış oldukları paylaşımları daire modeline aktarmalarından kaynaklanmıştır. Öğrenciler bu çalışmada daire modelini eş parçalara ayırırken bir merkez noktasından başlamaları gerektiğini ya da çift sayıdaki parçaya ayırmak ile tek sayıdaki parçaya ayırmak arasında farklı yollar geliştirmeleri gerektiğini anlayamamışlardır. Nitekim bu yöndeki etkinlikler aslında öğrencilerin kesir kavramını öğrendikleri ilk günden itibaren yapılması gerektiğinden ve öğrencilerin bu güçlüklerini gidermeye çalışmak araştırmanın amacı dışında olduğundan bu araştırma kapsamında hazırlanan TÖYH için yukarıda ifade edilen değişiklikleri yapmanın uygun olduğu düşünülmektedir. Ancak öğrenciler kesir kavramını öğrenirken ve kesir karşılaştırması yaparken daire modelinin kullanıldığ daha fazla örnek üzerinde çalışırlarsa, modeli eş parçalara ayırırken bir merkez noktasından başlamaları gerektiği ya da çift ve tek sayılı parçaya ayırmak için farklı stratejiler geliştirmeleri gerektiği konusunda farklı muhakeme yolları geliştirebilirler. Dolayısıyla kesirlerde toplama ve çıkarma işlemine geçildiğinde de daire modeli etkin bir yol olarak kullanılabilir. Öte yandan alınan ilk karar Cramer, Wyberg ve Leavitt'in (2008) çalışmalarında da benzer şekilde gerçekleştirilmiştir. Öğrencilerin öncelikle kâğıt katlama, sayma nesneleri gibi somut materyaller üzerinde çalışmışlar daha sonra daire modelini kesirlerde toplama ve çıkarma işlemi için etkili şekilde kullanabilmişlerdir.

Uygulama sonrasında yapılan bir diğer değişiklik ise yine küme modeli kullanmaktan kaynaklı ortaya çıkan yanılgılar sebebiyle yapılmıştır. Öğrenciler küme modelinde nesnelerin her birini bütün olarak ele almış, kümenin sahip olduğu eleman sayısına odaklanamamışlardır. 
Dolayısıyla küme modeliyle gösterilen bir bütün üzerinde, verilen kesre düşen eleman sayısını belirlerken güçlük yaşamışlardır. $\mathrm{Bu}$ güçlük öğrencilerin mevcut kesir bilgilerindeki eksikliklerden; daha ayrıntılı bir ifadeyle öğrencilerin kesir kavramına ve kesirlerin bütün temsil kullanımlarına hâkim olmadıklarından kaynaklandığı söylenilebilir. Alan-yazında var olan çalışmalarda öğrencilerin kesir kavramını öğrenirken alan ve uzunluk modelini kavramalarının ardından küme modeliyle uğraşmaları gerektiğini önerilmektedir (Behr, Wachsmuth, \& Post, 1984). Dolayısıyla bu araştırmada öğrencilerin küme modelini kullanımı konusunda yaşadıkları güçlüklerden dolayı küme modelinin kullanımı bu yol haritası için etkinliklerden çıarılmasının uygun olduğu düşünülmektedir. Ancak yapılacak diğer kesir çalışmaları için öğrencilerin alan ve uzunluk modeli üzerinde uzmanlaşmalarının ardından, küme modeli üzerinde çalışmak öğrencilerin kesir konusunu kavramaları için yararlı olacaktır (Rational Number Project [RNP], 2001).

Sonuç olarak daire modelinin ve küme modelinin kullanımında yapılan değişiklikler dışında hazırlanmış olan kesir kavramı ile kesirlerde toplama-çıkarma işlemine ilişkin hazırlanmış olan TÖYH öğrencilerin bu konuları öğrenirken kullanılabilecek bir model sunduğu araştırma sonuçlarıyla kanıtlanmıştır. Bu yol haritası öğrencilerin kesirlerde toplama ve çıkarma konusunu öğrenirken kullanılabilecek öğretim tasarımına yönelik bir model oluşturmaktadır. Bir sonraki bölümde araştırmanın diğer bulgularına ilişkin sonuçlardan bahsedilmiştir.

\section{Araştırmadan elde edilen diğer sonuçlar}

$\mathrm{Bu}$ araştırmada kesir kavramı ile kesirlerde toplama ve çıarma işlemine yönelik bir TÖYH geliştirilmiş ve bu yol haritasının uygulaması gerçekleştirilmiştir. Yukarıdaki bölümde araştırma sonucunda yapılan değişiklikler ayrıntılı olarak yapılmış ve değişikliklerin ardından TÖYH son halini almıştır. Geliştirilen bu TÖYH dışında araştırma sürecinde başka önemli sonuçlara da ulaşılmıştır.

Araştırma sonucunda oluşturulan TÖYH'si sayesinde öğrencilerin kesirlerde toplamaçıkarma konusunda kavramsal bir anlayışa ulaştıkları görülmüştür. Bunun nedeni ise öğrencilerin ön bilgilerinin tamamlanması olarak açıklanabilir. Bu araştırma beş hafta boyunca devam etmiş ve ilk dört haftanın büyük bir çoğunluğunda öğrencilerin ön bilgilerinin tamamlanmasıyla vakit geçirilmiştir. Oysaki öğrenciler daha önce öğrendikleri kesir, birim kesir ve denk kesir kavramlarında kavramsal bir anlayışa ulaşmış olsalardı, toplama-çıkarma işleminin öğretimi daha kısa sürede gerçekleştirilip, öğretmenlerin arzuladıkları alıştırma zamanına daha fazla zaman ayrılabilecekti. Türkiye'de öğretmenlerin öğretim programının yapılandırmacı bir yaklaşım ile uygulanamaması yönünde ilettikleri şikâyetler birçok araştırma sonucu olarak alan-yazında yer almaktadır (Ocak \& Ateş, 2015). Süre kısıtlllığı, materyal eksikliği, okullara girişte var olan sınav kaygısı gibi nedenlerle öğretim programının yaklaşımına yönelik olumsuz görüş bildirmişlerdir (Ocak \& Ateş, 2015). Oysa öğrenciler sahip olmaları gereken ön bilgileri kavramsal bir şekilde öğrendiklerinde, yeni konunun kavramsal olarak kazanımının kolaylaştığı da söylenebilir. Nitekim bu araştırmanın sonucu da bunu açık bir şekilde kanıtlamıştır. Öğrenciler kesir, birim kesri ve denk kesir kavramını kavramsallaştırmalarının ardından kesirlerle toplama ve çıkarma işlemini hem kolay ve hızlı bir şekilde öğrenmiş; hem de bu işlemlerle ilgili işlemsel beceriyi de kazanmışlardır.

Araştırma sürecinde ulaşılan bir diğer sonuç ise öğrencilerin birim kesir ve denk kesir kavramlarını bilmelerinin kesirlerde toplama ve çıkarma işleminin öğretimini kolaylaştırdığıdır. 
Altıncı Sınıf Öğrencilerinin Kesirler ve Kesirlerdeki Toplama-Çıkarma Konusundaki Bilgilerinin Yapılandırılmasına İlişsin Tahmini Öğrenme Yol Haritası

TÖYH'nin uygulanması sürecinde öğrenciler kesir kavramını öğrenip eş paylaştırma yapma konusunda uzmanlaştıktan sonra birim kesir ve denk kesir kavramları üzerine etkinlikler yapılmıştır. Öğrencilerin birim kesri iyice kavramsallaştırdıklarında; bu kavramın denk kesir kavramını ve bunun ardından ise kesirlerde toplama ve çıkarma işlemini öğrenmeyi desteklediği görülmüştür. $\mathrm{Bu}$ sonuç alan-yazındaki birçok araştırma ile de desteklenmektedir (Charalambous, Delaney, Hsu, \& Mesa, 2010; Clarke, Roche, \& Mitchell, 2008; Lamon, 2001). Lamon (2001) birimlere ayırma olarak adlandırılan, diğer bir ifadeyle birim kesirlerin bulunmasına yönelik yapılacak etkinliklerin hem denk kesirleri hem de orantısal muhakemeyi desteklediğini ifade etmektedir. $\mathrm{Bu}$ araştırmanın sonucu da hem bu öneriyi desteklemekte, ayrıca birim kesir öğreniminin kesirlerde toplama-çıkarma için öğrencilerin kullanabileceği en önemli fikir olduğunu ve aynı zamanda toplama-çıkarma işlemini kavramsal olarak anlamalarını kolaylaştırdığını doğrulamaktadır. $\mathrm{Bu}$ sonuçtan hareketle öğretmenlerin öğretimlerinde bu fikri geciktirmeden ve sürekli olarak derslerinde kullanmaları, öğrencilerin kesirlerde işlemler konularını öğrenmelerine katkı sağlayacağı söylenebilir.

Öğrencilerin işlemsel kural ya da terimlere odaklanmak yerine kavramsal bilgiye odaklandıklarında daha iyi öğrendikleri bir diğer önemli sonuç olarak ele alınabilir. Araştırma boyunca uygulamayı yapan öğretmen pay, payda gibi terimlerden ya da payda eşitlemek gibi işlemsel kurallardan ziyade kavramsal bilgiye odaklanmıştır. Bu da NCTM'nin (2014) belirlediği etkili bir öğretim için gereken işlemsel becerilerin kavramsal bir anlama ile ulaşılması yönünde yapmış olduğu önerinin bir uygulaması olarak ortaya çıkmaktadır. Örneğin bir kesirde kesir sayısının altında yer alan sayının payda olduğunu vurgulamak yerine, bütünün kaç eşit parçaya ayrılması gerektiğini ifade eden değer olarak ele alınmıştır. Bir diğer örnek ise iki kesri toplarken paydaları eşitlemek kuralının verilmesi yerine, öğrencilerin kesirleri toplayabilmek için model üzerinde birim kesirlerin eşitlenmesi gerektiği sonucuna ulaşmaları sağlanmıştır. $\mathrm{Bu}$ kavramsal yaklaşım sayesinde öğrenciler kesirlerle toplama-çıkarma işlemlerini daha kolay ve kavramsal olarak öğrenebilmişlerdir. Bu tür bir öğretim yaklaşımı "Rasyonel Sayı Projesi”nin öğretim programında da yer almaktadır (RNP, 2001). Projenin öğretim programında da kesirlerin sıralanması, denk kesirler ve kesirlerle işlemler için gereken sembolik prosedürden ziyade kesirle ilgili niceliksel hissin gelişimine vurgu yapılmaktadır. Bununla birlikte Hiebert'te (1999) öğretim programlarının sembol ve algoritmalarla yapılacak çalışmalardan ziyade kavramsal bilginin gelişimine odaklanılması gerektiğini ifade etmektedir. Yapılmış olan bu araştırmada da izlenilen kavramsal yaklaşımın öğrencilerin öğrenmesine destek verdiğini göstermiştir.

Son olarak yapılan bu araştırma çoklu temsil kullanımının öğrencilerin kavramsal öğrenmelerine büyük katkı sağladığını ortaya koymuştur. TÖYH'nin hazırlanmasında çoklu temsillerin kullanımına özellikle önem verilmiştir. Süreç boyunca daire modeli ve küme modeli üzerinde daha önce ifade edilen değişiklikler yapıldıktan sonra araştırma boyunca kullanılan alan ve uzunluk modelleri ve günlük yaşam bağlamları öğrencilerin hem kesir kavramını geliştirmelerine hem de kesirlerde toplama ve çıkarma işlemleri yapabilmelerine katkı sağladığ 1 söylenebilir. Örneğin kesirler ile işlem yapabilmek için alan modeli üzerinde birim kesirleri eşitlemeleri, öğrencilerin kesirlerle toplama yaparken neden paydayı eşitlemeleri gerektiğini görünür kılmış ve daha anlamlı bir öğrenme gerçekleştirmelerini sağlamıştır. Öte yandan kullanılan günlük yaşam bağlamları benzer şekilde öğrencilerin problemleri çözerken daha iyi 
performans göstermelerini sağlamıştır. Kesirlerde toplama ve çıkarma konusunda kullanılan öğrencilerin aşina oldukları günlük yaşam bağlamlarının, öğrencilerin işlem yapmalarını kolaylaştırdığı ve işlemleri daha iyi anlamlandırmalarına destek olduğu görülmüş̧ür. Çoklu temsillerin kesirlerin öğretiminde kullanılmasının önemi zaten birçok araştırmacı tarafından da desteklenmektedir (Cramer, Wyberg, \& Leavitt, 2008; Lamon, 2001). Nitekim araştırmanın bu sonucu da alanyazında var olan çalışmaların sonuçlarıyla benzerlik göstermiştir.

\section{Öneriler}

$\mathrm{Bu}$ araştırmada kesirler ile kesirlerde toplama-çıkarma işlemlerine yönelik TÖYH geliştirilmiş ve araştırmada konuyla ilgili birçok sonuca ulaşılmıştır. Araştırmanın sonuçları doğrultusunda diğer matematik eğitim araştırmacılarına, öğretmen adayları ile öğretmenlere, öğretim programı tasarlayıcılarına ve ders kitabı yazarlarına birçok öneride bulunulabilir.

İlk olarak öğretmenlerin yapılandırmacı bir öğretim için zamanlarının yetmediği yönünde belirtikleri şikâyetlerin aslında öğretimlerinde kavramsal öğrenme için yeterince zaman ayırmamalarından kaynaklandığını bu araştırma göstermiştir. Bu sonuçtan yola çıkarak ortaokul matematik öğretmenlerine öğretimlerinde çoklu temsilleri çok sık kullanmaları, sınıflarında yeterince tartışma ortamı oluşturmaları, öğrencilerin konularla ilgili ön bilgilerini tamamlamaları ve hatta kendileri de bu araştırmada hazırlanan TÖYH'ye benzer yol haritaları oluşturup test ederek geliştirmeleri önerilmektedir. Nitekim Lesh de (1979) yapmış olduğu araştırma sonucunda oluşturduğu model ile öğrencilere matematiksel fikirleri birçok yolla (somut materyaller, resimler, yazılı semboller, gerçek yaşam bağlamları kullanarak ve bu temsiller arasında dönüşümler yaparak) keşfederek öğrenmeleri için firsatlar sunulması gerektiğini önermektedir.

Türkiye'de matematik eğitimi araştırmaları incelendiğinde, araştırmacıların ders tasarladığı ya da öğretim modeli ortaya koydukları çok fazla çalışma yer almamaktadır. Dolayısıyla bu araştırmada yapıldığı gibi aynı konuda ya da matematiğin diğer öğrenme alanı ya da konularında geliştirilip test edilecek TÖYH'nin, hem matematik eğitimi araştırmalarını zenginleştireceği hem de öğretmenlere öğretim programı tasarlayıcılarına yol gösterici olacağ söylenebilir. Bu noktadan hareketle araştırmacılara farklı konularda ve öğrenme alanlarında geliştirecekleri TÖYH'yi test edecekleri araştırmalar yapmaları önerilmektedir. Ayrıca matematik eğitimi araştırmacılarına farklı öğrenme alanlarında ortaya konulan TÖYH'lerin sınıf içinde test edilmesinin ardından, bu yol haritalarının bireysel gelişime nasıl katkı sunduğuna yönelik öğrencilerin bilişsel modellerine ilişkin gelişimlerinin incelenmesi önerilmektedir. Bireysel olarak öğrencilerin bilişsel yapılarının nasıl geliştiğine yönelik yapılacak çalışmalar, yeni TÖYH'lerin planlamasında, öğretim etkinliklerinin seçiminde ve sıralamasında yol gösterici bir model olarak kullanılabilir.

$\mathrm{Bu}$ araştırma da kesirlerin öğretiminde çoklu temsillerin kullanımına, daire modellerinin ve küme modellerinin kullanımına yönelik sonuçlar ve kesir ile kesirlerde toplama-çıkarma işlemine yönelik bir TÖYH ortaya konulmuştur. Hem öğretim programını tasarlayan araştırmacılara hem de ders kitabı yazarlarına, öğretim programında ve ders kitaplarında yer alan bölümleri araştırmanın sonuçlarından yola çıkarak deneysel olarak test edilmiş araştırma sonuçlarına göre yeniden revize etmeleri ve benzeri araştırma sonuçlarını dikkate alarak kazanım ve konu anlatımı sıralamalarını düzenlemeleri önerilmektedir. 


\section{Kaynakça}

Bailey, D. H., Hoard, M. K., Nugent, L., \& Geary, D. C. (2012). Competence with fractions predicts gains in mathematics achievement. Journal of Experimental Child Psychology, 113(3), 447-455.

Ball, D. L. (1993). Halves, pieces, and twoths: Constructing and using representational contexts in teaching fractions. In T. P. Carpenter, E. Fennema, \& T. A. Romberg (Eds.), Studies in mathematical thinking and learning. Rational numbers: An integration of research (pp. 157-195). Hillsdale, NJ, US: Lawrence Erlbaum Associates, Inc.

Behr, M., Lesh, R., Post, T., \& Silver E. (1983). Rational Number Concepts. In R. Lesh \& M. Landau (Eds.), Acquisition of mathematics concepts and processes, (pp. 91-125). New York: Academic Press.

Behr, M., Harel, G., Post, T., \& Lesh, R. (1992). Rational number, ratio and proportion. In D. Grouws (Ed.), Handbook of research on mathematics teaching and learning (pp. 296-333). NY: Macmillan Publishing.

Behr, M., Wachsmuth, I., Post, T., \& Lesh, R. (1984). Order and equivalence relations: A clinical teaching experiment. Journal for Research in Mathematics Education, 15(5), 323-341.

Biber, A. Ç., Tuna, A., ve Aktaş, O. (2013). Öğrencilerin kesirler konusundaki kavram yanılgıları ve bu yanılgıların kesir problemleri çözümlerine etkisi. Trakya Üniversitesi Eğitim Fakültesi Dergisi, 3(2), 152-162.

Bottge, B. A., Ma, X., Gassaway, L., Butler, M., \& Toland, M. D. (2014). Detecting and correcting fractions computation error patterns. Exceptional Children, 80(2), 237-255.

Charalambous, C. Y., Delaney, S., Hsu, H., \& Mesa, V. (2010). A comparative analysis of the addition and subtraction of fractions in textbooks from three countries. Mathematical Thinking and Learning: An International Journal, 12(2), 117-151.

Clarke, D. M., Roche, A., \& Mitchell, A. (2008). Ten Practical Tips for Making Fractions Come Alive and Make Sense. Mathematics Teaching in the Middle School, 13(7), 372-380.

Common Core State Standards Initiative. (2011). About the standards. Retrieved from http://www.corestandards.org/about-the-standards. Erişim tarihi:

Cramer, K. A., Post, T. R., \& Delmas, R. C. (2002). Initial fraction learning by fourth-and fifth-grade students: A comparison of the effects of using commercial curricula with the effects of using the rational number project curriculum. Journal for Research in Mathematics Education, 33(2), 111-144.

Cramer, K., Wyberg, T., \& Leavitt, S. (2008). The role of representations in fraction addition and subtraction. Mathematics teaching in the middle school, 13(8), 490-496.

DeWolf, M., \& Vosniadou, S. (2015). The representation of fraction magnitudes and the whole number bias reconsidered. Learning and Instruction, 37, 39-49.

Fennell, F., \& Karp, K. (2017). Fraction Sense: Foundational Understandings. Journal of learning disabilities, 50(6), 648-650.

Gökkurt, B., Soylu, Y. \& Demir, Ö. (2015). Ortaokul matematik öğretmenlerinin kesirlerin öğretimine yönelik görüşlerinin incelenmesi. Necatibey Ĕ̈itim Fakültesi Elektronik Fen ve Matematik Ĕgitimi Dergisi, 9(2), 230-251.

Greeno, J. G. (1997). On claims that answer the wrong questions. Educational Researcher, 26, 5-17.

Hiebert, J. (1999). Relationships between research and the NCTM standards. Journal for research in mathematics education, 30(1), 3-19. 
Kieren, T. E. (1993). Rational and fractional numbers: From quotient fields to recursive understanding. In P. T. Carpenter, E. Fennema, \& T. A. Romberg (Eds.), Rational numbers: An integration of research (49-84). Newyork: Routledge.

Lamon, S. (2001). Presenting and representing: From fractions to rational numbers. In A. Cuoco \& F. Curcio (Eds.), The roles of representations in school mathematics-2001 yearbook (pp. 146-165). Reston: NCTM.

Lesh, R. (1979). Mathematical learning disabilities: Considerations for identification, diagnosis, and remediation. In R. Lesh, D. Mierkiewicz, \& M. G. Kantowski (Eds.), Applied mathematical problem solving (pp. 111-180). Columbus, OH: ERIC/SM.

Milli Eğitim Bakanlı̆̆ı [MEB] (2017). Matematik dersi ögretim programı (İlkokul ve Ortaokul 1,2,3,4,5,6, 7. ve 8. sinıflar). Ankara: Talim Terbiye Kurulu Başkanlığı.

Moss, J., \& Case, R. (1999). Developing children's understanding of the rational numbers: A new model and an experimental curriculum. Journal for research in mathematics education, 30(2), 122-147.

National Council of Teachers of Mathematics [NCTM]. (2000). Principles and standards for school rnnthematics. Reston, VA: National Council of Teachers of Mathematics.

National Council of Teachers of Mathematics. (2014). Principles to actions: Ensuring mathematics success for all. Reston, VA: National Council of Teachers of Mathematics.

Ocak, G., \& Ateş, F. Ç. (2015). Matematik dersinde yapılandırmacı yaklaşımın uygulanabilirliğinin öğretmen görüşleri açısından değerlendirilmesi. Uluslararası Alan Eğitimi Dergisi, 1(2), 1-23.

Pesen, C. (2007). Students' misconceptions about fractions. Eğitim ve Bilim, 32(143), 79-88.

Rational Number Project. (2001). [On-line].

Available: http://www.cehd.umn.edu/ci/rationalnumberproject/ Erişim tarihi: 8.05.2018.

Reys, B. J., Kim, O. K., \& Bay, J. M. (1999). Establishing fraction benchmarks. Mathematics teaching in the middle school, 4(8), 530 .

Simon, M. A., \& Tzur, R. (2004). Explicating the role of mathematical tasks in conceptual learning: An elaboration of the hypothetical learning trajectory. Mathematical thinking and learning, 6(2), 91-104.

Simon, M. (2014). Hypothetical learning trajectories in mathematics education. In Encyclopedia of Mathematics Education (pp. 272-275). Springer Netherlands.

Simon, M. A. (1995). Reconstructing mathematics pedagogy from a constructivist perspective. Journal for research in mathematics education, 26(2), 114-145.

Simon, M. A. (2000). Research on the development of mathematics teachers: The teacher development experiment. A. E. Kelly \& R. A. Lesh (Eds.) in Handbook of research design in mathematics and science education (335-360), London: Lawrence Erlbaum Associates Publishers.

Simon, M. A., Tzur, R., Heinz, K., \& Kinzel, M. (2004). Explicating a mechanism for conceptual learning: Elaborating the construct of reflective abstraction. Journal for research in mathematics education, 35(5), 305-329.

Steffe, L. P., \& Thompson, P. W. (2000). Teaching experiment methodology: Underlying principles and essential elements. In R. Lesh \& A. E. Kelly (Eds.), Research design in mathematics and science education (pp. 267- 307). Hillsdale, NJ: Erlbaum.

Tunc-Pekkan, Z. (2015). An analysis of elementary school children's fractional knowledge depicted with circle, rectangle, and number line representations. Educational Studies in Mathematics, 89, 419-441.

Van de Walle, J. A., Karp, K. S., \& Bay-Williams, J. M. (2004). Elementary and middle school mathematics. Boston: Allyn and Bacon.

Wilson, P. H., Mojica, G. F., \& Confrey, J. (2013). Learning trajectories in teacher education: Supporting teachers' understandings of students' mathematical thinking. The Journal of Mathematical Behavior, 32(2), 103-121. 
Altıncı Sınıf Öğrencilerinin Kesirler ve Kesirlerdeki Toplama-Çıkarma Konusundaki Bilgilerinin Yapılandırılmasına İlişkin Tahmini Öğrenme Yol Haritası

Wilson, P. H., Sztajn, P., Edgington, C., \& Confrey, J. (2014). Teachers' use of their mathematical knowledge for teaching in learning a mathematics learning trajectory. Journal of Mathematics Teacher Education, 17 (2), 149-175.

Yıldırım, A \& Şimşek, H. (2011). Sosyal bilimlerde nitel araştırma yöntemleri. Ankara: Seçkin Yayınc1lı.

Zembat, İ. Ö. (2016). Matematik Öğretim Döngüsü ve 'Tahmini Öğrenme Yol Haritaları'. Erhan Bingölbali, Selahattin Arslan, \& İsmail Özgür Zembat (Ed.), Matematik Eğitiminde Teoriler içinde (s.509-518). Ankara: Pegem Akademi.

EK-1

Aşağıdaki taralı alanların ifade ettiği kesirleri yazınız.
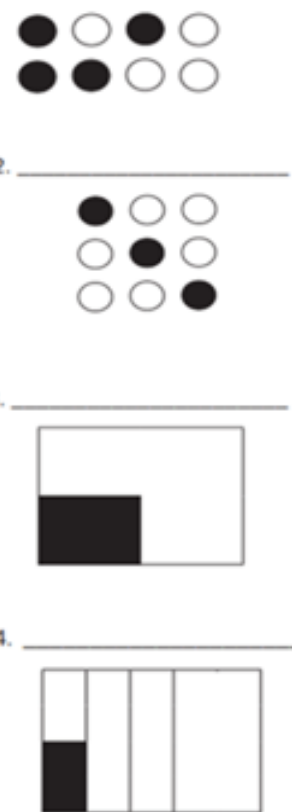

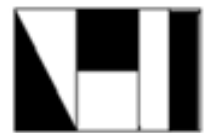

6.

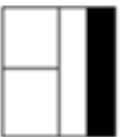

Aşağıdaki modellerin $\frac{3}{4}$ 'ü temsil etme durumlarını tartışınız.
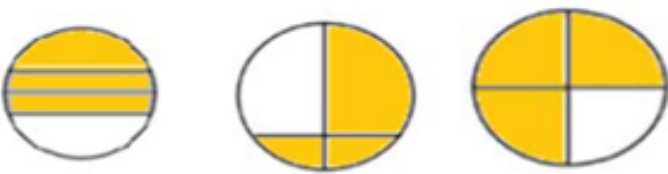


\section{Extended Abstract}

\section{Introduction}

Fractions are one of the most difficult and complex topics in elementary school mathematics, both in terms of teaching and learning. Indicated research results on students' failure in fractions and teachers' inadequate approaches to teaching fractions reveal the necessity of research for teaching fractions. From this point of view, the purpose of this study is to develop a hypothetical learning trajectory that supports understanding of sixth grade elementary students' addition and subtraction in fractions and to suggest a teaching design on these topics. According to the research purpose, research questions formulated as follows:

1. What are design decisions taken in the process of developing activities related to the concept of fractions and addition-subtraction in fractions, also why are these decisions taken?

2. How is the final form of hypothetical learning trajectory developed by testing for fractions and the addition-subtraction in fractions?

\section{Methodology}

This research is designed as a teaching experiment which is often used in mathematics education research. 16 sixth grade students attended the study in a public school located on the Central Anatolia Region. Data collection proceeded throughout mathematics classes, two class hours per week for five weeks. In order to assess students' prior knowledge, a pretest including eight open-ended questions were administered to students. As a result of this test and in the direction of students' teacher, students have difficulties about the meaning of fractions, unit fraction, and types of fractions. The learning objectives and activities for students were determined in the lesson plans based on hypothetical learning trajectories, and hypothesis about the students' progress were made in the learning process. HLT were revised after each lesson according to the students' difficulties during the lesson and test after the lesson by the teacher and the researcher. All of the lessons throughout the teaching experiment were video-recorded.

Data were collected by lesson videos, test administered after lessons, students' homework, and researcher's field notes. Data were analyzed by using the ongoing analysis and retrospective analysis. In the ongoing analysis, the teacher and the researcher watched lesson videos each week and analyzed students' homework in order to determine students' difficulties and learned concepts, and then they make decisions intended to teaching process and revised the teaching activities. In the retrospective analysis, lesson videos were transcribed and all data sources were analyzed.

\section{Results and Discussion}

In the first phase of the formation of the hypothetical learning trajectory, the students' prior knowledge has been analyzed. According to the pre-test results, students have difficulties on explaining the meaning of fractions, determining the unit fraction, and comparing fractions, in addition, they have misconceptions about the types of fractions. Therefore, considering the pretest results before teaching the addition and subtraction in fractions, goals were created 
Altıncı Sınıf Öğrencilerinin Kesirler ve Kesirlerdeki Toplama-Çıkarma Konusundaki Bilgilerinin Yapılandırılmasına İlişkin Tahmini Öğrenme Yol Haritası

according to the students' prior knowledge for each week. Lessons were planned by taking into the consideration of intended goals.

In the development of hypothetical learning trajectory about addition and subtraction in fractions, first of all, it was considered to overcome students' difficulties, and to use various representations. Equipartitioning, different meanings of fractions, unit fractions and equivalent fractions which were the prior knowledge for addition and subtraction in fractions, were included at the center of the HLT. In the teaching of these concepts, it is planned to utilize all the different types of representation and daily life contexts that are appropriate. At the end of the teaching experiment, a hypothetical learning trajectory and a teaching design for fraction addition and subtraction was proposed. This hypothetical learning trajectory provides a model for instructional design that can be used when students are learning about addition and subtraction in fractions.

Results revealed that, students conceptually learn addition and subtraction in fractions through the constructed HLT. The reason of this result can be explained as the completion of the prior knowledge of the students. Furthermore, it was revealed that students have learned fraction operations conceptually through the teaching sequence and the multiple representations used in the proposed instructional design for teaching fraction addition and subtraction. Another result was that students who learn unit fractions and equivalent fractions easily learn the addition and subtractions in fractions. In other words, it could be inferred that knowledge about unit fractions and equivalent fractions are necessary to learn fraction operations. The other important result is that when students learn the conceptual knowledge instead of focusing on procedural rules, they learn and development better fluency for operations. Finally, it was revealed that multiple representations has contributed to students' conceptual understanding. In line with the results of the research, many suggestions have been made to other mathematics education researchers, teacher candidates and teachers, curriculum designers and textbook authors. 